\title{
Phosphorylation of Cell Surface Receptors: A Mechanism for Regulating Signal Transduction Pathways
}

\author{
DAVID R. SIBLEY, JEFFREY L. BENOVIC, MARC G. CARON, AND \\ ROBERT J. LEFKOWITZ
}

Howard Hughes Medical Institute, Departments of Medicine, Biochemistry and Physiology, Duke University Medical Center, Durham, North Carolina 27710

\section{Introduction}

$\mathrm{S}$ PECIFIC receptors, located in the plasma membranes of cells, are crucially involved in mediating the acute and chronic effects of a wide variety of hormones, drugs, growth factors, antigens, and other ligands. Some membrane receptors are involved in transporting various important molecules into the cell by a process known as receptor-mediated endocytosis. An important insight which has emerged from recent research is that both the function and subcellular distribution of many such receptors are dynamically regulated.

Phosphorylation/dephosphorylation represents perhaps the most intensively studied reversible covalent modification of enzymes which is known to have regulatory significance $(1,2)$. Considerably more is known about the kinases than the phosphatases. Only recently has it begun to be appreciated that the function of noncatalytic proteins, such as receptors, may also be regulated in this way. We review here the important plasma membrane receptor systems thus far studied whose function and/or cellular trafficking has been demonstrated to be regulated by phosphorylation. Available information suggests a number of principles which may be generally applicable as well as several testable hypotheses.

\section{$\beta$-Adrenergic Receptor-Coupled Adenylate Cyclase}

The $\beta$-adrenergic receptor-coupled adenylate cyclase system may be considered to be prototypical of a wide variety of receptors which are coupled to their effector systems via guanine nucleotide regulatory $(G)$ proteins. $\mathrm{G}$ proteins represent a family of closely related proteins which are heterotrimeric consisting of GTP binding and hydrolyzing $\alpha$-subunits as well as $\beta$ - and $\gamma$-subunits (3-

\footnotetext{
Address requests for reprints and all correspondence to: Dr. David R. Sibley, Experimental Therapeutics Branch, Building 10, Room 5C108, National Institutes of Health, Bethesda, Maryland 20892.
}

5). Receptors may either stimulate adenylate cyclase via the stimulatory guanine nucleotide regulatory protein $\left(G_{s}\right)$ or inhibit it via the inhibitory guanine nucleotide regulatory protein $\left(\mathrm{G}_{\mathrm{i}}\right)$. It is now readily apparent that some forms of regulation of adenylate cyclase may be achieved through phosphorylation of its protein components. One of the most extensively investigated forms of this type of regulation is that of desensitization. Desensitization is defined as a process through which prolonged exposure of target cells to hormone, drug, or neurotransmitter agonists results in a diminished cellular responsiveness to further agonist stimulation.

Desensitization of $\beta$-adrenergic receptor-coupled adenylate cyclase is generally divided into two major categories (6-8). One form is referred to as agonist specific or homologous and is distinguished by the fact that only stimulation by $\beta$-adrenergic agonists is attenuated. Conversely, agonist-nonspecific or heterologous desensitization is characterized by diminished responsiveness to additional receptor agonists and to nonreceptor activators such as guanine nucleotides and fluoride ion. Investigations of homologous desensitization have demonstrated sequestration or down-regulation of the receptors away from the cell surface in addition to an uncoupling of receptor-adenylate cyclase interaction (6-8). Homologous desensitization does not appear to be mediated by cAMP as this form of refractoriness can be demonstrated in the absence of cAMP generation (6-8). Heterologous desensitization, by contrast, does not involve receptor sequestration or down-regulation but instead is primarily associated with functional uncoupling of the receptors from adenylate cyclase. Moreover, heterologous desensitization appears to be mediated, at least partially, by cAMP (6-8). Since heterologous desensitization is associated with decrements in fluoride ion and guanine nucleotide-stimulated activities (effectors which bypass the receptors) this form of desensitization must, at a minimum, involve alterations in either the regulatory proteins and/or the catalytic moiety of adenylate cyclase. 
Recent studies have, in fact, demonstrated that the stimulatory and perhaps the inhibitory guanine nucleotide regulatory proteins $\left(G_{s}\right.$ and $G_{i}$, respectively) are functionally modified in heterologous desensitization. Kassis and Fishman (9) demonstrated that $G_{s}$ extracted from heterologously desensitized fibroblasts and reconstituted into $\mathrm{S} 49 \mathrm{cyc}^{-}$cell membranes $\left(\mathrm{S} 49 \mathrm{cyc}^{-}\right.$cells lack $G_{8}$ but possess the other components of adenylate cyclase) was functionally impaired relative to controls. Similarly, heterologous desensitization induced by prostaglandin $E_{1}$ in liver (10) and by human CG in ovaries (11) results in an impaired functionality of $G_{s}$ as determined with $\mathrm{S} 49 \mathrm{cyc}^{-}$membrane reconstitution. In contrast, Rich et al. (12) have reported that glucagon-induced heterologous desensitization in MDCK cells was not associated with $G_{s}$ alterations but instead involved increases in the apparent levels of the inhibitory guanine regulatory protein, $\mathrm{G}_{\mathrm{i}}$. This suggests that alterations in the $G_{s} / G_{i}$ stoichiometry may be another mechanism by which heterologous desensitization is achieved.

Additional evidence for a functional alteration in $G_{8}$ in heterologous desensitization has come from studies with avian erythrocytes. Briggs et al. (13) found that when $G_{8}$ was extracted from catecholamine-desensitized turkey erythrocytes and carefully quantitated by labeling with $\left.{ }^{32} \mathrm{P}\right] \mathrm{NAD}^{+}$and cholera toxin, desensitization resulted in a significant reduction in the ability of $\mathrm{G}_{\mathrm{s}}$ to reconstitute adenylate cyclase activity in $\mathrm{S}_{4} 9 \mathrm{cyc}^{-}$membranes. Although heterologous desensitization can apparently result in impaired $G_{s}$ functionality, this does not exclude other potential lesions in the adenylate cyclase system. In fact, the observation that catecholaminestimulated adenylate cyclase activity is desensitized by about $50 \%$ whereas the fluoride ion and guanine nucleotide activities are reduced by only $10-20 \%$ after agonistinduced desensitization is indicative of other processes which occur as well $(6,13)$.

Indeed, using $\left[{ }^{32} \mathrm{P}\right]$ orthophosphate incorporation, it has been shown that during the heterologous desensitization in both avian and amphibian erythrocytes, the $\beta$ adrenergic receptor undergoes phosphorylation (14-16). Sibley et al. (15) have investigated this phosphorylation process in detail using turkey erythrocytes. In these cells, the $\beta$-adrenergic receptor is stoichiometrically phosphorylated under basal conditions containing $0.7-1.0 \mathrm{~mol}$ phosphate/mol receptor with this stoichiometry increasing to 2-3 $\mathrm{mol} / \mathrm{mol}$ upon maximal desensitization (15). This phosphorylation occurs exclusively on serine residues in the receptor $(16,17)$. We have also shown that the phosphate/receptor stoichiometry is tightly correlated with the degree of desensitization (15). For instance, the time courses for receptor phosphorylation and adenylate cyclase desensitization are identical as are the rates of resensitization and the return of the phos- phate/receptor stoichiometry to control levels (15). Moreover, incubation of the cells with membrane-permeable cAMP analogs causes submaximal phosphorylation of the $\beta$-adrenergic receptor which is correlated with the partial desensitization of adenylate cyclase which these analogs evoke (15). These data thus indicate that in erythrocytes, heterologous desensitization is tightly correlated with phosphorylation of the $\beta$-adrenergic receptor.

Since cAMP analogs can reproduce the catecholamineinduced receptor phosphorylation and desensitization in avian (15) and amphibian erythrocytes (16), then presumably the cAMP-dependent protein kinase is involved in this desensitization. In fact, Benovic et al. (18) have recently demonstrated a cAMP-mediated phosphorylation of mammalian lung $\beta$-adrenergic receptor that is similar to the process exhibited by erythrocytes. Using pure receptor and pure cAMP-dependent protein kinase, it is shown that isoproterenol enhanced the rate of receptor phosphorylation (on serine residues) by about 2fold. Reconstitution of the phosphorylated receptor with the $\mathrm{G}_{\mathrm{s}}$ protein demonstrated diminished agonist-promoted receptor-mediated stimulation of the GTPase activity compared with controls. Thus, the cAMP-dependent protein kinase-promoted phosphorylation is functionally significant. Since any hormone or drug that raises intracellular cAMP levels will presumably lead to such $\beta$-adrenergic receptor phosphorylation, this type of regulation is of the heterologous type.

A fascinating question concerning heterologous desensitization is why incubation of avian erythrocytes with cAMP analogs produces only partial effects (15). One hypothesis, suggested by Benovic et al. (18), is that in order to obtain maximal phosphorylation of the $\beta$-adrenergic receptor, agonist occupancy must occur. Another possibility is that the receptor phosphorylation is not completely mediated by cAMP and that other protein kinase systems may phosphorylate the $\beta$-adrenergic receptor as well. In this regard, we (19) and others (20) have shown that phorbol esters, compounds which potently activate protein kinase $\mathrm{C}$, are capable of stimulating $\beta$-adrenergic receptor phosphorylation concomitantly with adenylate cyclase desensitization. Interestingly, in duck erythrocytes (19) the phorbol ester-induced receptor phosphorylation is nonadditive with that produced by isoproterenol, suggesting a common mechanism or pathway of action.

Recently, protein kinase $\mathrm{C}$ has been shown to directly phosphorylate the purified $\beta$-adrenergic receptor in vitro albeit to a lower stoichiometry than that of the cAMPdependent protein kinase (21). The phosphorylation by protein kinase $\mathrm{C}$ occurs on serine residues and is not enhanced by agonist occupancy of the receptor. Importantly, the sites on the receptor that are phosphorylated 
by protein kinase $\mathrm{C}$ and the cAMP-dependent protein kinase appear to be identical as determined by peptide mapping techniques (21).

The relationship of the protein kinase $\mathrm{C}$ and cAMPdependent protein kinase phosphorylation sites has been further elucidated by recent molecular cloning and sequence analysis of the $\beta_{2}$-adrenergic receptor (22). Figure 1 shows the $\beta_{2}$-adrenergic receptor as it is proposed to be organized in the plasma membrane. As can be seen in Fig. 1, there are two sites on the receptor consisting of the general amino acid sequence Arg-Arg-X-Ser, which represents a consensus recognition site for the cAMPdependent protein kinase (23). Both of these sequences also contain a basic amino acid (lysine) either at or close to the carboxy-terminal side of the relevant serine residue, which renders these excellent recognition sites for protein kinase $C$ as well (24).

It thus appears as if protein kinase $\mathrm{C}$ and the cAMPdependent protein kinase both phosphorylate the $\beta$-adrenergic receptor on identical sites. The phosphorylation by the cAMP-dependent protein kinase is enhanced by receptor agonist occupancy and represents a classical negative feedback regulatory loop. Phosphorylation of the $\beta$-adrenergic receptor by protein kinase $\mathrm{C}$ may represent a cross talk pathway whereby receptor systems which stimulate phosphatidylinositol turnover and activate protein kinase $\mathrm{C}$ can negatively modulate adenylate cyclase-coupled receptors. In support of this hypothesis is the observation that muscarinic receptor agonists have been shown to promote $\beta$-adrenergic receptor desensitization in the heart where muscarinic receptors are coupled to phosphatidylinositol hydrolysis (25).

In summary, the molecular mechanisms which are thought to be involved in heterologous desensitization are shown in Fig. 2. In this form of desensitization, receptor function is regulated by phosphorylation in the absence of receptor sequestration or down-regulation.
This covalent modification serves to functionally uncouple the receptors, that is, to impair their interactions with the guanine nucleotide regulatory proteins. Several protein kinases seem to be capable of promoting phosphorylation of the receptors including the cAMPdependent kinase and protein kinase $\mathrm{C}$. In addition to the receptor modification, heterologous desensitization seems to be associated with functional modifications (phosphorylation?) at the level of the nucleotide regulatory proteins $\left(\mathrm{G}_{\mathrm{s}}\right.$ and $\left.\mathrm{G}_{\mathrm{i}}\right)$.

The mechanisms by which agonists promote homologous desensitization of the $\beta$-adrenergic receptor also appear to involve receptor phosphorylation. Evidence for this was first obtained using amphibian erythrocytes where $\beta$-adrenergic agonists were shown to promote homologous desensitization of adenylate cyclase and phosphorylation of $\beta$-adrenergic receptor (26). The agonistinduced receptor phosphorylation is pharmacologically specific and stoichiometric, occurring to about $2 \mathrm{~mol}$ phosphate/mol receptor. Prostaglandin $\mathrm{E}_{1}$ does not promote $\beta$-adrenergic receptor phosphorylation, although this hormone elevates cAMP levels in these cells. This suggests that the observed receptor phosphorylation is not mediated by the cAMP-dependent protein kinase. Additional evidence that protein kinase $A$ is not involved in homologous-induced receptor phosphorylation has come from studies using S49 lymphoma cells (27). It was observed that in the S49 mutant cell lines cyc ${ }^{-}$and kin-, which are deficient in the $\mathrm{G}_{\mathrm{s}}$ protein and cAMP-dependent protein kinase, respectively, agonists promoted $\beta$ adrenergic receptor phosphorylation to the same degree as in wild type cells. These results indicate that 1) receptor- $\mathrm{G}_{\mathrm{s}}$ coupling is not necessary for receptor phosphorylation to occur-agonist occupancy is sufficient; and 2) the receptor phosphorylation is not mediated by the cAMP-dependent protein kinase.

Benovic et al. (28-30) have recently identified and
Fig. 1. Structure of the $\beta$-adrenergic receptor as it is proposed to be organized in the plasma membrane. The sites of phosphorylation by the cAMP-dependent protein kinase (and probably protein kinase C) are indicated. The solid circles represent the serine- and threonine-rich region in the carboxy terminus which may serve as sites of $\beta$ ARK phosphorylation (see text).

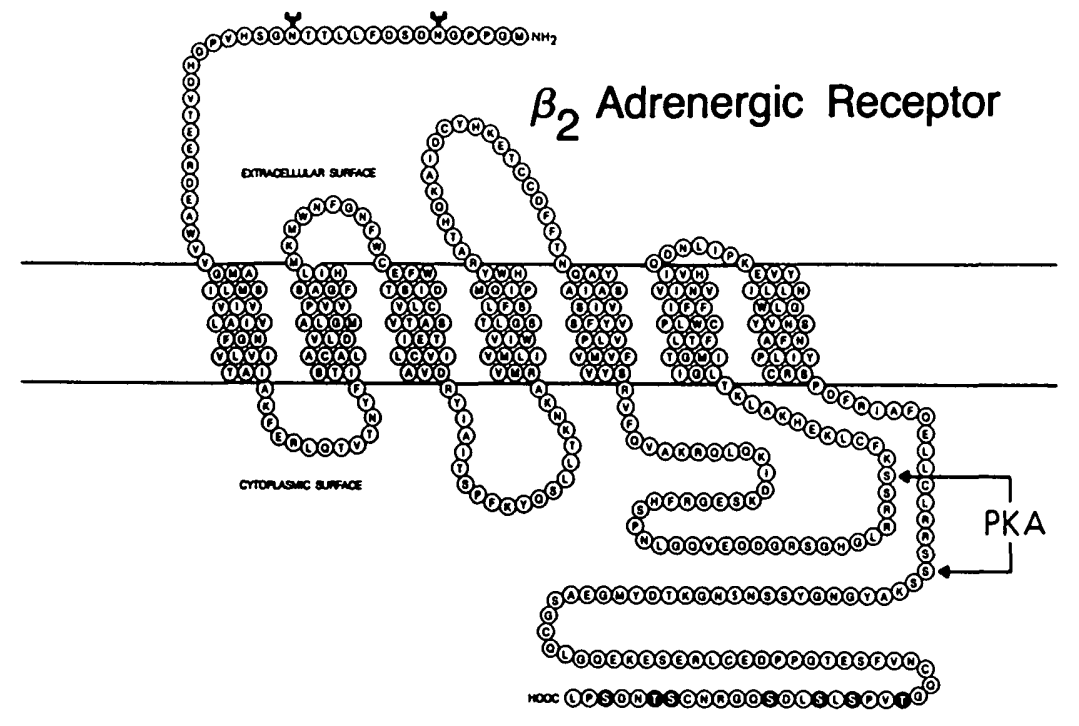




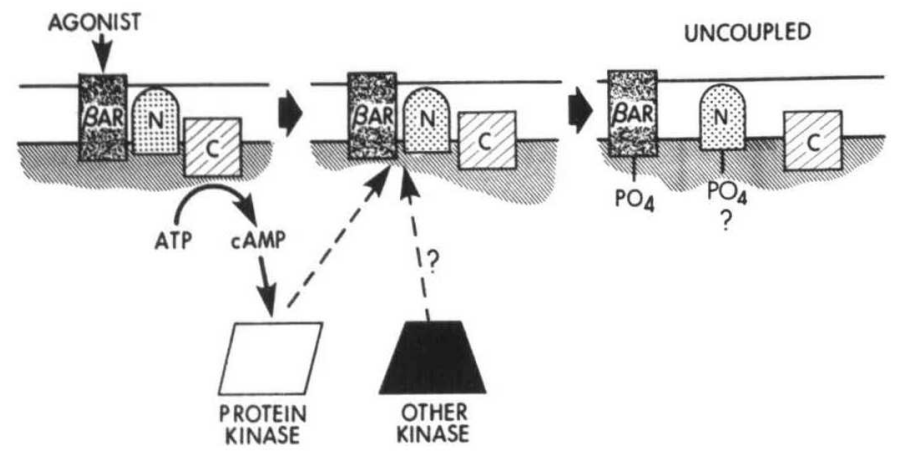

FIG. 2. Heterologous desensitization mechanisms of adenylate cyclase.

purified a novel protein kinase with phosphorylates the $\beta$-adrenergic receptor and may be involved in homologous desensitization. Referred to as the $\beta$-adrenergic receptor kinase (or $\beta A R K$ ), it is quite ubiquitous in mammalian tissues thus far examined and appears to be cytosolic. It has the unique property of phosphorylating only the agonist-occupied form of the receptor. The unoccupied or antagonist-occupied receptor is not a substrate for the enzyme. BARK is distinct from other protein kinases such as the cAMP-, cGMP-, $\mathrm{Ca}^{2+} / \mathrm{cal}-$ modulin-, and $\mathrm{Ca}^{2+} /$ phospholipid-dependent protein kinases. Moreover, $\beta$ ARK does not phosphorylate such general kinase substrates as casein or histones. Upon addition of $\beta$-adrenergic agonist to the cell, $\beta \mathrm{ARK}$ is translocated from the cytosol to the plasma membrane, where it phosphorylates the agonist-occupied receptor (31). The exact sites of $\beta$ ARK phosphorylation on the $\beta$ adrenergic receptor are not yet known, although, in analogy with the rhodopsin/rhodopsin kinase system (see below), the serine/threonine-rich carboxy terminus (Fig. 1 ) is a likely region.

A clear consequence of $\beta$-adrenergic receptor phosphorylation in homologous desensitization is a functional uncoupling of the receptors from the $\mathrm{G}_{\mathrm{s}}$ proteins. Sibley et al. (32) demonstrated that phosphorylated $\beta$-adrenergic receptors purified from amphibian erythrocytes are functionally impaired in reconstituting receptor- $G_{8}$ interactions in phospholipid vesicles when compared to controls. Similarly, purified $\beta$-adrenergic receptor which has been phosphorylated by $\beta$ ARK shows an impairment of function (J. L. Benovic et al., manuscript in preparation).

The molecular events which may be involved in homologous desensitization of the $\beta$-adrenergic receptor are shown in Fig. 3. Phosphorylation and uncoupling of the receptors from adenylate cyclase activation occur within minutes after agonist occupancy of the receptors (27, 32 ). Shortly thereafter the receptors become sequestered or internalized within the cells into low density membrane particles or vesicles, although the exact nature of this sequestered compartment is currently unknown, as
MOLECULAR MECHANISMS OF HOMOLOGOUS DESENSITIZATION

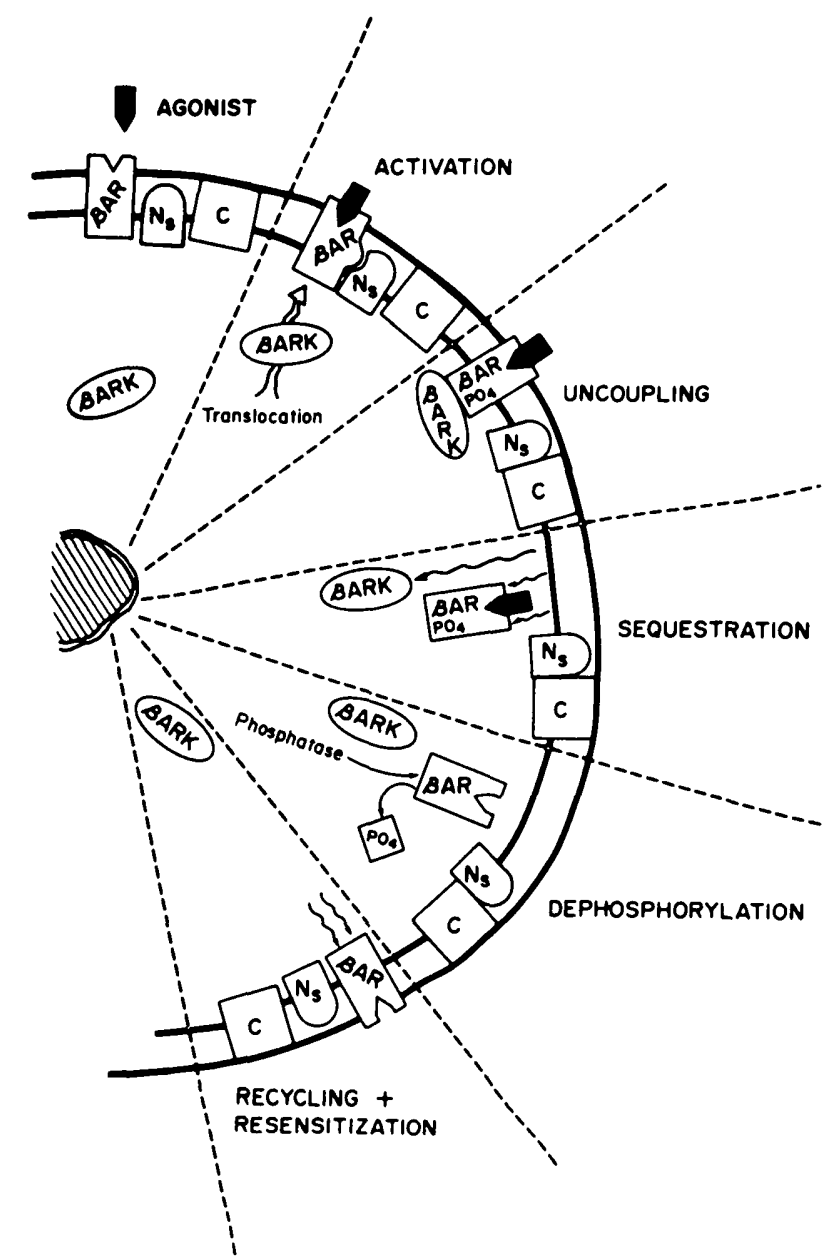

FIG. 3. Homologous desensitization of $\beta$-adrenergic receptor-coupled adenylate cyclase.

are the mechanisms of receptor translocation (6). For example, it is not known whether coated pits are involved or whether the receptor phosphorylation event triggers the redistribution of the receptors from the plasma membrane. Within the sequestered compartment the receptors become dephosphorylated and functionally regenerated (32). High levels of $\beta$-adrenergic receptor phosphatase activity appear to be associated with the sequestered membrane compartment (32). When agonist is removed or its concentration decreased sufficiently, the receptors can redistribute back to their basal levels in the plasma membranes.

As reviewed above, phosphorylation of the receptor components of the adenylate cyclase system appears to be important in dampening the hormonal signal. Recent studies, however, have suggested that phosphorylation of the catalytic components of the enzyme system may serve as an amplification mechanism. This was first suggested from experiments that involved treating cells with phorbol esters, compounds that potently activate 
protein kinase C (33), and examining their effects on adenylate cyclase activity. It was observed that phorbol ester treatment resulted in enhanced basal adenylate cyclase activity as well as that stimulated by a variety of hormonal and nonhormonal effectors (34-39). This amplification effect has also been demonstrated by the direct addition of activated protein kinase $\mathrm{C}$ to plasma membranes (40).

Using amphibian erythrocytes, we have demonstrated that incubation of these cells with phorbol esters results in a dramatic $100-300 \%$ amplification of $\beta$-adrenergic agonist-, prostaglandin-, guanine nucleotide-, as well as $\mathrm{Mn}^{2+}$, and forskolin-stimulated enzyme activities (34). The observation that the forskolin- and $\mathrm{Mn}^{2+}$-stimulated activities are increased is especially interesting since these compounds can directly stimulate the catalytic unit of adenylate cyclase. This suggests that protein kinase $\mathrm{C}$ may phosphorylate the catalytic unit resulting in amplified activity. In fact, using erythrocytes, we have demonstrated that activation of protein kinase $\mathrm{C}$ with phorbol esters results in stoichiometric phosphorylation of the catalytic unit of adenylate cyclase (41). Under basal conditions there is no observable phosphate incorporated into the catalytic unit purified from $\left[{ }^{32} \mathrm{P}\right]$-labeled cells, however, from phorbol ester-treated cells, the catalytic unit is phosphorylated to about $3 \mathrm{~mol}$ phosphate/mol enzyme. We have also shown that purified protein kinase $\mathrm{C}$ can directly phosphorylate the adenylate cyclase catalytic unit purified from bovine brain (41). This protein kinase C-catalyzed phosphorylation of the adenylate cyclase catalytic unit and amplification of enzyme activity may provide a physiological mechanism by which receptor systems that promote phosphatidylinositol turnover and protein kinase $\mathrm{C}$ activation can modulate receptor systems coupled to adenylate cyclase.

\section{Other G Protein-Coupled Receptors}

It has become increasingly apparent that diverse biological phenomena are characterized by adaptive processes analogous to the desensitization observed in $\beta$ adrenergic receptor-coupled adenylate cyclase systems. Not surprisingly, many of the other G protein-coupled receptors display desensitization phenomena qualitatively similar to those described above. Thus far, little information is available concerning the molecular mechanisms involved. It will be of interest to see whether these are identical to those uncovered for the $\beta$-adrenergic receptors.

A number of receptors, including $\alpha_{1}$-adrenergic and muscarinic cholinergic, which are coupled via $G$ proteins to phosphatidylinositol turnover and protein kinase $\mathrm{C}$ activation $(33,42)$ demonstrate regulatory phenomena similar to adenylate cyclase-coupled receptors. Most no- tably, the $\alpha_{1}$-adrenergic receptor-stimulated phosphatidylinositol turnover response in cultured smooth muscle cells has been shown to be desensitized by phorbol ester treatment $(43,44)$. Moreover, this desensitization is associated with phosphorylation of the $\alpha_{1}$-adrenergic receptor (44). More recently, it has been shown that $\alpha_{1}$ adrenergic agonists also promote $\alpha_{1}$-adrenergic receptor desensitization, sequestration, and phosphorylation in a temporally correlated fashion (45). Unlike the situation for the adenylate cyclase-coupled $\beta$-adrenergic receptors, there is as yet no evidence for specific receptor kinases involved in these phosphorylation reactions. In fact, it appears that protein kinase $\mathrm{C}$ itself directly phosphorylates the $\alpha_{1}$-adrenergic receptor and that the rate but not the extent of this reaction is enhanced by agonist occupancy (21). This is analogous to the cAMP-dependent protein kinase-mediated phosphorylation of the $\beta$-adrenergic receptor (18). A classical feedback loop thus presumably operates whereby diacylglycerol, generated by agonist stimulation of phosphatidylinositol turnover, activates protein kinase $\mathrm{C}$, which phosphorylates and desensitizes the $\alpha_{1}$-adrenergic receptor. The cAMP-dependent protein kinase will also directly phosphorylate the $\alpha_{1}$-adrenergic receptor in vitro, although agonists do not promote this reaction (21).

The situation for the muscarinic cholinergic receptor seems quite analogous to that of the $\alpha_{1}$-adrenergic receptor. Desensitization of muscarinic receptor-stimulated phosphatidylinositol hydrolysis and receptor down-regulation has been observed in response to cholinergic agonist or phorbol ester stimulation (46-50). Furthermore, Kwatra and Hosey (51) have recently demonstrated muscarinic receptor phosphorylation in cardiac tissue in response to agonist activation. The protein kinase(s) involved in this reaction has not yet been identified.

An additional $G$ protein-coupled receptor system which demonstrates well characterized adaptive phenomena is the rhodopsin system in retinal rod outer segments. As reviewed in detail elsewhere $(22,52)$, this system is structurally and functionally analogous to hormone-activated adenylate cyclase. The analogous components are a photon of light instead of hormone, rhodopsin instead of receptor, a GTP-binding and hydrolyzing protein termed transducin instead of $G_{8}$, and a cyclic GMP (cGMP) phosphodiesterase, which controls retinal concentrations of cGMP, instead of the catalytic unit of adenylate cyclase. Rhodopsin undergoes a phosphorylation reaction that is catalyzed by a specific kinase termed rhodopsin kinase (53-57). Phosphorylation by rhodopsin kinase requires the light (agonist) activated form of rhodopsin and occurs on multiple serine and threonine residues within the carboxy terminus of rhodopsin (58). Phosphorylation of rhodopsin results in 
an impaired ability of rhodopsin to interact with transducin. This system is thus desensitized by an agonistpromoted phosphorylation reaction that uncouples the receptor from its GTP-binding regulatory protein. Although phosphorylation of rhodopsin will reduce its interaction with transducin, an additional protein is required for complete uncoupling of this system. This protein, referred to as $48 \mathrm{~K}$ protein, $S$ antigen, or arrestin, only binds to the phosphorylated form of rhodopsin (59, 60 ). This observation raises the interesting hypothesis that there may be an analogous $48 \mathrm{~K}$ protein in the adenylate cyclase system whose action is necessary to express the full functional effects of receptor phosphorylation.

The picture that emerges from these findings is of a variety of pathways by which $G$ protein-coupled receptors are regulated. There are classical feedback regulatory loops, such as the protein kinase A phosphorylation of the $\beta$-adrenergic receptor or protein kinase $\mathrm{C}$ phosphorylation of the $\alpha_{1}$-adrenergic receptor. The rates of these reactions are enhanced by agonist occupancy of the receptors. Cross-talk pathways also exist by which, for example, protein kinase $\mathrm{C}$ can phosphorylate the adenylate cyclase-coupled $\beta$-adrenergic receptor or protein kinase $\mathrm{A}$ the $\alpha_{1}$-adrenergic receptor. These reactions are not promoted by agonist occupancy of the substrate receptor. Although their physiological regulatory significance is less clear, these reactions could play an important amplification role in tissues where a physiological or biochemical response of the target cell is reciprocally controlled by hormones using two distinct signal transduction pathways. Finally, there are specific receptor kinases, such as rhodopsin kinase and $\beta \mathrm{ARK}$, which phosphorylate and desensitize specific receptors in a completely agonist-dependent fashion. Such kinases lead only to agonist-specific or homologous desensitization since agonist-promoted conformational changes in the receptor are required to transform them into substrates for the regulatory enzyme.

\section{Insulin Receptors}

Insulin induces a wide variety of biological effects in target cells leading to alterations in cellular metabolism and growth. These actions are mediated by specific high affinity cell surface receptors. Insulin receptors are integral membrane glycoproteins comprised of two $\alpha$-subunits $\left(M_{r} \cong 130,000\right)$ and two $\beta$-subunits $\left(M_{r} \cong 90,000\right)$ linked by disulfide bonds (reviewed in Refs. 61 and 62). Insulin appears to interact with the $\alpha$-subunit of the receptor which results in enhanced tyrosine kinase activity which is intrinsic to the $\beta$-subunit. Both the $\alpha$ - and $\beta$-subunits are known to be derived from a single glycosylated precursor protein $M_{r} \cong 190,000$. Recently, com- plementary DNAs (cDNAs) encoding the precursor have been cloned which predict a polypeptide consisting of either $1,370(63)$ or $1,382(64)$ amino acids. The $\alpha$-subunit comprises the $\mathrm{N}$-terminal portion of the precursor, followed by an enzyme cleavage site and then the $\beta$-subunit containing a single transmembrane spanning sequence. The $\beta$-subunit also contains a protein kinase domain which exhibits homology with the epidermal growth factor (EGF) receptor and the src family of tyrosine kinases. A schematic representation of the insulin receptor is shown in Fig. 4.

Although the physiological effects of insulin receptor stimulation are well known, the initial biochemical signals have been difficult to elucidate. One of the earliest measurable responses to insulin stimulation, however, is that of receptor phosphorylation. Kasuga et al. $(65,66)$ initially demonstrated that insulin stimulates phosphorylation of the $\beta$-subunit of the receptor in ${ }^{32} \mathrm{P}$-labeled lymphocytes and hepatoma cells. Similar results have been observed using isolated adipocytes (67) and rat

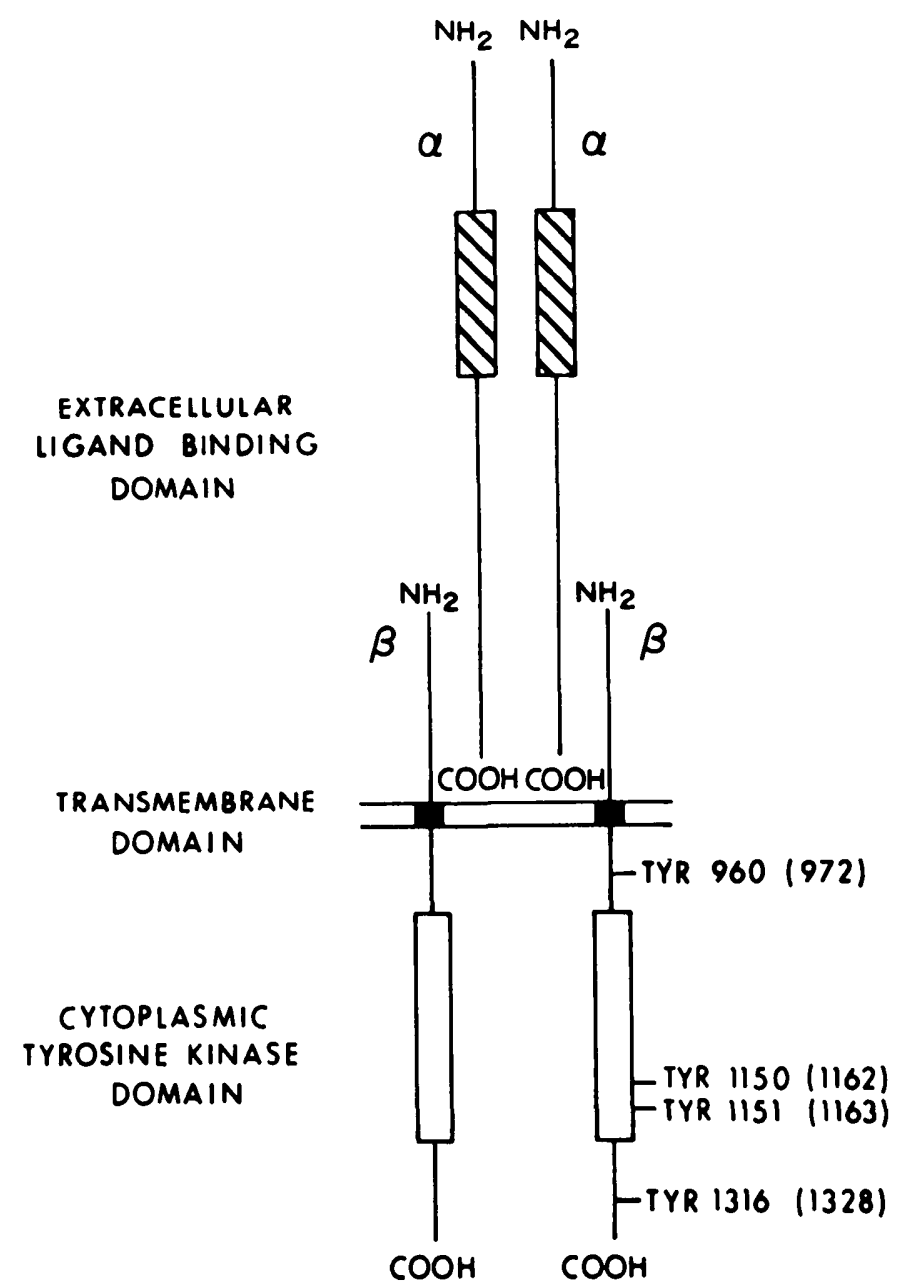

FIG. 4. Schematic representation of the insulin receptor. Regions of high cysteine concentration are shown as hatched boxes, transmembrane domains as solid boxes, and tyrosine kinase domains as open boxes. 
hepatocytes (68). In most cells, under basal conditions the $\beta$-subunit contains predominantly phosphoserine and to a lesser extent phosphothreonine. Upon addition of insulin to the cells, increased levels of phosphoserine and phosphothreonine are observed in addition to phosphorylation of tyrosine residues in the $\beta$-subunit $(67,68-$ 75). Interestingly, Pang et al. (71) have shown that the insulin-stimulated tyrosine phosphorylation temporally precedes the increased serine phosphorylation of the $\beta$ subunit. Peptide mapping of the phosphorylated $\beta$-subunits from intact cells indicates the presence of multiple sites of serine, and to a lesser extent threonine, phosphorylation whereas the tyrosine phosphorylation occurs on two to three major distinct sites (72-74). Recently, Stadtmauer and Rosen (76) have presented evidence suggesting that tyrosine $1,150^{1}$ is one of the phosphorylated residues in insulin-stimulated cells (Fig. 4). In intact cells, the $\alpha$-subunit does not appear to be phosphorylated.

In contrast to intact cells, when insulin-stimulated receptor phosphorylation is examined under cell-free conditions, using $\left[\gamma^{32} \mathrm{P}\right] \mathrm{ATP}$, phosphorylation occurs exclusively on tyrosine residues. A large number of laboratories have characterized this reaction using solubilized insulin receptors in various stages of purity from a variety of tissues (see Refs. 61, 62, and 77 for review and references). It has been well documented that the cellfree phosphorylation is a result of autophosphorylation of the $\beta$-subunit and that the insulin receptor itself is a tyrosine kinase. Autophosphorylation of the $\beta$-subunit appears to be intramolecular as dilution of insulin receptors does not decrease the rate of $\beta$-subunit phosphorylation $(78,79)$. The $\beta$-subunit possesses an ATP binding site (80-82), and the cloned sequence predicts a protein kinase domain with homology to other tyrosine kinases $(63,64)$. Tyrosine phosphorylation of the $\alpha$-subunit has also been observed under cell-free conditions $(83,84)$; however, as this subunit appears to be extracellular (Fig. 4), this reaction may not be physiologically significant.

Reports on the stoichiometry of insulin receptor phosphorylation indicate that in vitro the $\beta$-subunit is phosphorylated up to $2 \mathrm{~mol}$ phosphate/mol receptor $(78,79)$. Peptide mapping of the in vitro phosphorylated $\beta$-subunit indicates that there are two to three distinct sites of tyrosine phosphorylation $(72,74,78,79,85)$. In the study of White et al. (72), two of the in vitro phosphorylation sites corresponded to the two tyrosine phosphorylation sites which were observed in intact cells.

Evidence is now available which indicates that the

\footnotetext{
${ }^{1}$ The two reported amino acid sequences for the insulin receptor precursor differ in that the sequence of Ebina et al. (64) contains an insertion of 12 amino acids in the carboxy terminus of the $\alpha$-subunit when compared to that of Ullrich et al. (63). In this review, we will refer to the sequence of Ullrich et al. (63) when designating amino acid residues.
}

activity of the insulin receptor tyrosine kinase is enhanced by tyrosine phosphorylation of its $\beta$-subunit. Rosen et al. (86) initially showed that autophosphorylation of the receptor results in increased tyrosine kinase activity as measured with exogenous substrates. Moreover, after autophosphorylation, the activated tyrosine kinase is rendered insulin independent. Dephosphorylation of the receptor with alkaline phosphatase restores the insulin dependency of the tyrosine kinase. Other laboratories have shown that autophosphorylation of the receptor both in vitro $(85,87)$ and in intact cells $(74,88)$ leads to enhanced tyrosine kinase activity of the $\beta$ subunit. In the studies of $\mathrm{Yu}$ and Czech (85) and Kwok et al. (87) the enhanced activity correlated with the phosphorylation of a single tryptic peptide site.

Using antibodies directed to peptides derived from the known sequence of the $\beta$-subunit, Herrera and Rosen (89) have provided evidence that tyrosines 1150 and 1316 (Fig. 4) are autophosphorylated in vitro. It was further shown that autophosphorylation of Tyr-1150, which is also phosphorylated in intact cells (76), is best correlated with kinase activation. Interestingly, antibodies directed against the sequence containing Tyr-960 block autophosphorylation and thus exogenous kinase activity (90), yet this residue does not appear to be autophosphorylated in vitro (76). Using microsequencing techniques, Tornqvist et al. (91) have also demonstrated in vitro autophosphorylation of tyrosine residues 1150 and 1316 as well as tyrosines 1146,1151 , and 1322 . Recently, Ellis et al. (92) have demonstrated that point mutations in tyrosines 1150 and 1151 will reduce insulin-stimulated autophosphorylation and tyrosine kinase activity in parallel with a decrease in insulin-stimulated 2-deoxyglucose uptake when expression is performed in CHO cells. Taken together, these results argue strongly for a role of autophosphorylation of tyrosines 1150 and 1151 in activation of tyrosine kinase activity, although the molecular mechanism by which this activation occurs is not yet understood.

The observation that in intact cells insulin receptors undergo phosphorylation on serine and threonine residues in addition to tyrosine residues suggests that other protein kinases are involved in regulating insulin receptor function. A role for the cAMP-dependent protein kinase has been suggested by Pessin et al. (93) who showed that incubation of adipocytes with $\beta$-adrenergic agonists, which raise intracellular cAMP levels, inhibit high affinity binding of insulin to its receptor. Insulinstimulated glucose transport is also inhibited, and these effects are mimicked by incubation with dibutyrylcAMP. Haring et al. (94) have reported similar findings and further showed that $\beta$-adrenergic agonist treatment of cells reduces the tyrosine kinase activity of the receptor by increasing its Michaelis-Menten constant $\left(\mathrm{K}_{\mathrm{m}}\right)$ 
for ATP. Similarly, Stadtmauer and Rosen (75) demonstrated that increasing the cAMP of IM-9 cells diminishes insulin receptor tyrosine kinase activity and that this is correlated with increased serine and threonine phosphorylation on the $\beta$-subunit. Although these data suggest that cAMP leads to attenuation of insulin action by altering the phosphorylation state of the insulin receptor, it is not clear whether the cAMP-dependent protein kinase directly phosphorylates the receptor. Inspection of the amino acid sequence of the $\beta$-subunit indicates the absence of classic consensus recognition sites for this enzyme $(63,64)$ suggesting that multiple kinases may be involved in this modification.

Protein kinase $\mathrm{C}$ also appears to be involved in regulating insulin receptor function. Treatment of cells with phorbol esters, which activate protein kinase $\mathrm{C}$, results in increased phosphorylation of serine and threonine residues in the $\beta$-subunit $(69,73,95,96)$. In some cells, but not others, this modification results in a reduction in affinity of insulin for binding to the receptor. Takayama et al. (69) and Haring et al. (96) have shown that phorbol ester-induced receptor phosphorylation additionally results in a reduction of tyrosine kinase activity of the $\beta$-subunit. Recently, Bollag et al. (97) demonstrated that protein kinase $\mathrm{C}$ can directly phosphorylate the $\beta$-subunit of the insulin receptor in vitro to stoichiometric levels. This phosphorylation is accompanied by a $65 \%$ reduction in the tyrosine kinase activity of the receptor.

As noted earlier, treatment of intact cells with insulin results in enhanced receptor phosphorylation on serine and threonine residues. Peptide mapping experiments indicate that these residues appear, for the most part, to be distinct from those phosphorylated in response to protein kinase $C$ activation $(69,73)$. This may suggest that insulin treatment leads to the activation of other serine/threonine kinases or that insulin occupancy of the receptor renders it a better substrate for those kinases. Recent results have indicated that long term insulin treatment of cells can lead to reductions in receptor tyrosine kinase activity $(98,99)$ which may be linked to the observed insulin-induced increase in serine/threonine phosphorylation.

Insulin receptors thus appear to be under both positive and negative control through phosphorylation of their $\beta$ subunits. One of the earliest events in insulin activation is autophosphorylation of the $\beta$-subunit leading to enhanced tyrosine kinase activity toward exogenous substrates. Tyr-1150 and 1151 appear to be intimately involved in this phosphorylation although other tyrosine residues cannot be ruled out as yet. In contrast, phosphorylation of the $\beta$-subunit on serine and perhaps threonine residues results in decreased autophosphorylation and tyrosine kinase activity of the receptor. The serine and threonine residues involved in this modification have not yet been identified. A number of serine/threonine protein kinases may be involved in this phosphorylation including the cAMP-dependent protein kinase and protein kinase $\mathrm{C}$. Whether or not insulin occupancy results in receptor phosphorylation by additional kinases remains to be determined.

\section{Insulin-Like Growth Factor (IGF) Receptors I and II}

IGF-1 or somatomedin $\mathrm{C}$ is a polypeptide growth factor with an amino acid sequence which is highly homologous to insulin. IGF-I initiates its mitogenic response in target cells by binding to specific receptors on the plasma membrane. Like the insulin receptor, the IGF-I receptor is a disulfide-linked heterotetramer that can be resolved into $M_{r} \cong 130,000 \alpha$-subunits which bind IGF-I and $M_{r}$ $\cong 98,000 \beta$-subunits which exhibit tyrosine kinase activity (100). In analogy with the insulin receptor, IGF-I receptor $\alpha$ - and $\beta$-subunits are encoded with a single $M_{r}$ $\cong 180,000$ glycosylated receptor precursor for which cDNAs have been recently cloned and sequenced (101).

As with the receptor for insulin, the IGF-I receptor is a tyrosine protein kinase capable of autophosphorylation. Incubation of ${ }^{32} \mathrm{P}$-labeled IM-9 and Hep-G2 cells with IGF-I promotes phosphorylation on tyrosine residues of the IGF-I receptor $\beta$-subunit (73). In addition, in both partially and highly purified preparations of IGF-1 receptors, IGF-I stimulates phosphorylation of tyrosine residues on the $\beta$-subunit of the receptor $(95,102-107)$. Evidence has been presented that this is an intramolecular reaction $(105,107)$. As with insulin receptors, autophosphorylation of the IGF-I receptor is believed to enhance its tyrosine kinase activity. IGF-I receptor-mediated phosphorylation of exogenous tyrosine-containing substrates is enhanced by prior autophosphorylation, and this enhancement is reversed by phosphatase treatment of the receptor $(105,107)$.

In intact cells, the $\beta$-subunits of the IGF-I receptor are constitutively phosphorylated on serine and threonine residues (73). Incubation of cells with biologically active phorbol esters increase this serine and threonine phosphorylation by about 4 -fold $(73,95)$. In IM-9 cells, IGFI also promotes serine and threonine phosphorylation on the $\beta$-subunit, although apparently on different sites than those observed with phorbol esters (73). The functional significance of these serine and threonine phosphorylations is at present unclear; however, in some cells phorbol esters have been shown to reduce IGF-I binding activity (108).

Like IGF-I, IGF-II is a peptide hormone which is structurally homologous with insulin. The receptor for IGF-II is distinct from the IGF-1 receptor and is com- 
posed of a single polypeptide with $\mathrm{M}_{\mathrm{r}} \cong 250,000$ (109). The IGF-II receptor appears to be functionally different from insulin and IGF-I receptors in that binding of IGFII to its receptor does not directly trigger acute metabolic or growth-permissive effects. Moreover, the IGF-II receptor does not appear to possess tyrosine kinase activity (110). Rather it has been suggested that internalization and recycling of the IGF-II receptor may be closely linked to IGF-II action (111). Interestingly, Oka et al. $(112,113)$ have observed that insulin treatment of adipocytes leads to increased numbers of IGF-II receptors in the plasma membrane. In addition, there is a concomitant decrease in IGF-II receptors located in a low density microsomal membrane compartment.

Corvera and Czech (114) have investigated the molecular basis of this phenomenon and demonstrated a role for IGF-II receptor phosphorylation. They found that under basal conditions about $80-90 \%$ of the total cellular IGF-II receptors reside in a microsomal fraction with $10-20 \%$ being located in the plasma membrane. Moreover, the receptors in the plasma membrane are stoichiometrically phosphorylated possessing 2 - to 3 -fold more phosphate than those receptors in the microsome fraction. Insulin treatment produces a specific and dramatic decrease in the phosphorylation state of the plasma membrane receptors which is correlated with the appearance of receptors on the cell surface. These data suggest a model in which the IGF-II receptor is persistently phosphorylated on the cell surface leading to internalization into a microsomal compartment where dephosphorylation can occur. Insulin perturbs this process by inhibiting the IGF-II receptor kinase or activating a phosphatase or both which leads to decreased internalization and increased IGF-II receptor expression on the cell surface. Interestingly, this model is analogous to that describing the role of phosphorylation in $\beta$-adrenergic receptor sequestration and recycling (see above).

The nature of the protein kinase(s) involved in IGF-II receptor phosphorylation is at present not known. Corvera et al. (110), however, have demonstrated that the IGF-II receptor can be phosphorylated by a tyrosine kinase in adipocyte membranes although, as mentioned above, this is not an autophosphorylation event.

\section{The EGF Receptor}

EGF is a polypeptide mitogen which is capable of stimulating the proliferation of a variety of epidermal and epithelial cells (115). The receptor for EGF is a 170,000 dalton glycosylated transmembrane protein which exhibits intrinsic tyrosine kinase activity (115, 116). Activation of the receptor with EGF leads to enhanced intracellular protein phosphorylation on tyrosine residues (see Refs. 77, 117, and 118 for reviews). Recent molecular cloning of the EGF receptor indicates that it consists of 1,186 amino acids, contains a single membrane-spanning domain, and exhibits an extracellular amino terminus and a cytosolic carboxy terminus (119121). The tyrosine kinase domain of the receptor is in the cytoplasmic region and demonstrates high homology to the transforming protein v-erb $\mathrm{B}$ of avian erythroblastosis virus (122). A schematic representation of the EGF receptor is shown in Fig. 5. In intact cells, the EGF receptor is constitutively phosphorylated on serine, threonine, and tyrosine residues (123-125). Evidence has accumulated suggesting that these phosphorylation sites may be intimately linked with regulating receptor function.

Stimulation of the EGF receptor with EGF rapidly leads to receptor autophosphorylation on tyrosine residues (reviewed in Refs. 77 and 115-118). Downward et al. (126) have shown that tyrosine residues $1,068,1,148$, and 1,173 in the carboxy terminus are involved in this autophosphorylation with residue 1,173 being the most heavily phosphorylated (Fig. 5). This reaction was shown by Weber $e t$ al. (127) to be intramolecular in nature. Gill and colleagues $(128,129)$ have suggested that this auto-

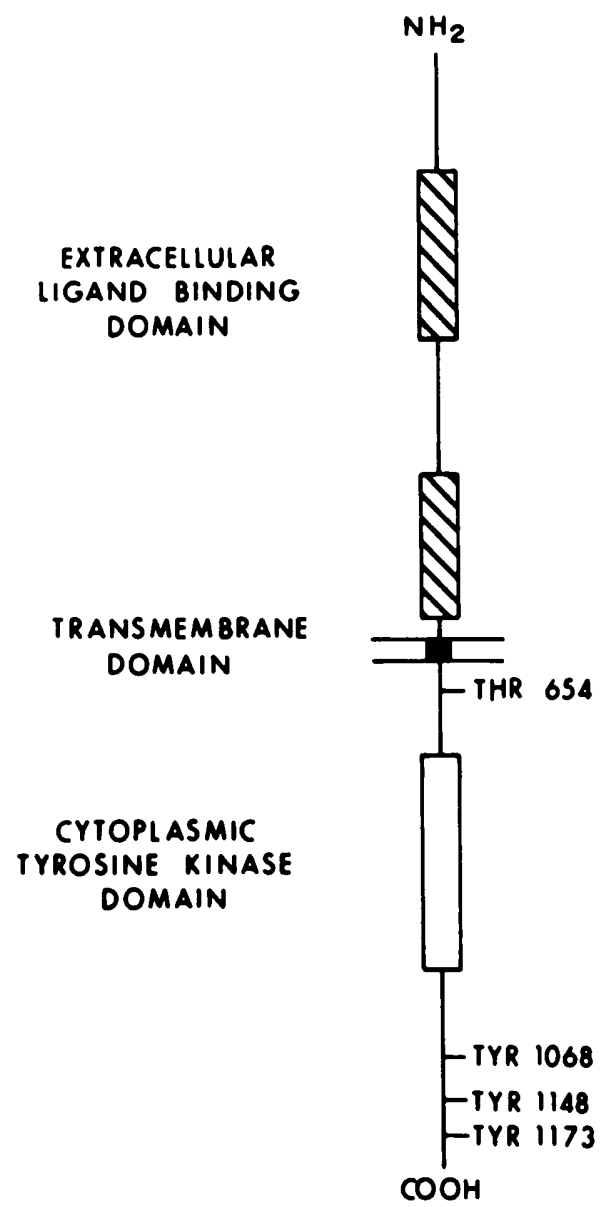

FIG. 5. Schematic representation of the EGF receptor. Regions of high cysteine concentration are shown as hatched boxes, the transmembrane domain as a solid box, and the tyrosine kinase domain as an open box. 
phosphorylation enhances the tyrosine kinase activity of the receptor. When phosphorylation of exogenous peptide substrates is assayed as a function of receptor autophosphorylation, tyrosine kinase activity is enhanced by up to 3-fold at a phosphate/receptor stoichiometry of 1-2 $\mathrm{mol} / \mathrm{mol}$. High concentrations of peptide substrates can inhibit phosphorylation of both the receptor and the peptides, but this inhibition can be relieved by initially autophosphorylating the receptor. These results suggest then that autophosphorylation of the carboxy terminus may remove an inhibitory steric constraint, thus allowing access of exogenous substrates to the active site and increased tyrosine kinase activity.

In contrast to the above studies, an early report by Cassel et al. (130) indicated that EGF-induced autophosphorylation of the EGF receptor in A431 cell membranes does not affect its tyrosine kinase activity. In addition, the rate of EGF-induced exogenous peptide phosphorylation does not show a lag during the time period in which receptor phosphorylation was' submaximal. Similarly, Downward et al. (131) have provided evidence that variation in the extent of receptor autophosphorylation from 0.1-2.8 mol phosphate $/ \mathrm{mol}$ receptor does not. influence receptor kinase activity either in purified or membranebound receptor preparations. Moreover, Gullick et al. (132) have shown that antibodies raised against synthetic peptides containing; the EGF receptor tyrosine autophosphorylation sites can inhibit autophosphorylation of the native receptor without affecting EGF-stimulated tyrosine kinase activity toward exogenous substrates. In addition, Yarden and Schlessinger (133) have presented evidence favoring an intermolecular rather than an intramolecular mechanism of EGF receptor activation. It is thus not yet clear whether receptor autophosphorylation on tyrosine residues results in enhanced tyrosine kinase activity of the EGF receptor. It is expected that experiments involving site-directed mutagenesis of the relevant tyrosine residues in the EGF receptor will resolve this important issue.

In addition to phosphorylation on tyrosine residues, treatment of intact cells with EGF results in enhanced phosphorylation of serine and threonine residues in the receptor (123-125, 134). Since EGF has been shown to promote phosphatidylinositol turnover $(135,136)$ generating diacylglycerol which activates protein kinase $\mathrm{C}$ (137), it was proposed that this kinase phosphorylates the receptor. Indeed, a number of studies have demonstrated that treatment of cells with phorbol esters, which directly activate protein kinase $\mathrm{C}$, results in attenuation of EGF binding to its receptor (138-144). Moreover, phorbol esters induce phosphorylation of serine and threonine residues in the EGF receptor in intact ${ }^{32} \mathrm{P}$-labeled cells $(124,125,134,145,146)$. Although treatment of cells with phorbol esters enhances phosphorylation of both serine and threonine residues, peptide mapping experiments indicate the appearance of unique peptides containing only phosphothreonine $(124,134,145,146)$. Hunter et al. (145) and Davis and Czech (147) have identified threonine 654 in the EGF receptor as the unique site of phosphorylation in response to phorbol esters in intact cells. This residue is located on the cytoplasmic side of the receptor nine residues away from the plasma membrane (Fig. 5). It is thus in an ideal location to affect interaction between the extracellular and intracellular domains of the receptor. Protein kinase $\mathrm{C}$ added directly to A431 cell membranes will also phosphorylate the EGF receptor on the same sites as those promoted by phorbol esters (134).

Phosphorylation of EGF receptors by protein kinase $\mathrm{C}$ appears to inhibit receptor tyrosine kinase activity. Cells exposed to phorbol esters exhibit decreased phosphotyrosine levels in EGF receptors and other proteins $(124,134,148)$. These studies also demonstrated that EGF-induced autophosphorylation of the receptor on tyrosine residues is reduced after phorbol esters treatment. Recently, Downward et al. (131) have also shown that phosphorylation of the EGF receptor by protein kinase $\mathrm{C}$ results in decreased tyrosine kinase activity toward exogenous substrates.

As discussed previously, phosphorylation of the EGF receptor by protein kinase $C$ (via phorbol ester treatment) results in functional alterations in EGF binding. In some cells this is apparent as a reduction in the high affinity component of EGF-receptor binding, whereas in others the result is a decrease in the number of EGF receptors at the cell surface. Davis and Czech (149) have shown that reduction of the apparent affinity of the EGF receptor by protein kinase $\mathrm{C}$ correlates with phosphorylation of threonine 654 but not with phosphorylation of other residues on the receptor. Lin et al. (150) have further shown that mutating threonine 654 to an alanine residue blocks phorbol ester-induced EGF receptor internalization in a cellular expression system. These data suggest that phosphorylation of threonine 654 by protein kinase $\mathrm{C}$ regulates the affinity of the receptor for EGF, the activity of the tyrosine kinase domain, as well as the intracellular location of the receptor.

It should be noted that the mechanisms by which EGF induces internalization of its receptor may be distinct from those mediated by the actions of phorbol esters. First, phorbol esters appear to promote internalization of EGF receptors in the absence of receptor degradation $(151,152)$, whereas EGF promotes both internalization and degradation (153). Moreover, in the study of Lin et al. (150) the alanine 654 mutant receptors were still internalized and degraded in response to EGF. There thus appears to be two independent mechanisms by which EGF receptors are internalized. One of these in- 
volves phosphorylation on threonine 654 of the receptor and can be promoted by both phorbol esters and EGF (154). The other, which is promoted only by EGF, also leads to receptor degradation and may or may not involve phosphorylation. In this regard, it is interesting that monoclonal antibodies to the EGF receptor can promote receptor internalization in the apparent absence of phosphorylation (155).

Although EGF stimulation leads to rapid autophosphorylation on tyrosine residues which may result in enhanced kinase activity. EGF treatment also results in the phosphorylation of threonine 654 (154) leading to eventual receptor internalization and tyrosine kinase inhibition (156). In addition to this negative feedback loop induced by EGF, the protein kinase C-induced receptor phosphorylation may also represent a mechanism of heterologous regulation by other hormone ligands which activate protein kinase C. Platelet-derived growth factor (PDGF), fibroblast growth factor, bombesin, and vasopressin, all of which stimulate phosphatidylinositol turnover, decrease EGF binding to its receptor (157161). Davis and Czech (162) have further shown that PDGF will induce phosphorylation on threonine 654 of the EGF receptor. Moreover, synthetic derivatives of diacyglycerol, the endogenous activator of protein kinase C, will promote EGF receptor phosphorylation (163165).

The EGF receptor is also potentially regulated through phosphorylation by the cAMP-dependent protein kinase. This kinase has been shown to phosphorylate membranebound and purified EGF receptor on serine and threonine residues $(166,167)$. Evidence that this phosphorylation may be physiologically significant has come from studies of Pessin et al. (93). They observed that treatment of adipocytes with both $\beta$-adrenergic agonists, which increase intracellular cAMP levels, and with dibutyrylcAMP leads to a decreased affinity of the receptor for EGF. Phosphorylation of the EGF receptor by the cAMP-dependent protein kinase may thus lead to inhibition of EGF action.

\section{The PDGF Receptor}

PDGF is one of the major mitogens found in serum which stimulates DNA and protein synthesis as well as amino acid uptake and phosphatidylinositol turnover in a number of cells (168): Interestingly, PDGF is structurally homologous with the product of the $\mathrm{v}$-sis oncogene (169). The PDGF receptor has been identified by affinity cross-linking experiments as a $M_{r} \cong 180,000$ single polypeptide glycoprotein $(170,171)$. Like the receptors for insulin, EGF and IGF-I, the PDGF receptor posseses tyrosine kinase activity. Initial studies using fibroblast membranes demonstrated that PDGF promotes the in- corporation of phosphate into tyrosine residues of a $\mathrm{M}_{\mathrm{r}}$ $\cong 180,000$ protein (172-174). Pike et al. (175) and Heldin et al. (170) subsequently provided evidence suggesting that the phosphoprotein observed in fibroblast membranes is the PDGF receptor. It was also observed that the $M_{r} \cong 180,000$ protein contains phosphoserine and phosphothreonine which are enhanced upon PDGF treatment (175). The PDGF receptor has been recently purified using a novel antiphosphotyrosine antibody (176-178). These studies indicate that the $M_{r} \cong 180,000$ substrate of the PDGF-stimulated tyrosine kinase is, in fact, the PDGF receptor and like the other tyrosine kinase receptors is capable of autophosphorylation. Very recently, the primary structure of the PDGF receptor has been obtained through molecular cloning techniques (179). The single polypeptide contains an extracellular ligand binding domain, a single membrane spanning region, and an intracellular tyrosine kinase domain which is homologous with other tyrosine kinases (179).

Since the functional consequences of PDGF receptor autophosphorylation are not yet known, it will be interesting to investigate whether this covalent modification is linked to tyrosine kinase activation as suggested for the other tyrosine kinase receptors. Similarly, it will be important to establish a role for the phosphorylation of the PDGF receptor on serine and threonine residues (175) and to identify the kinase(s) involved. Since PDGF promotes phosphatidylinositol turnover in several cell types, it is tempting to speculate that protein kinase $\mathrm{C}$ may somehow be involved in these phosphorylation events. However, a recent report by Sturani et al. (180) has suggested that phorbol esters do not affect PDGF receptor function, at least in fibroblasts.

\section{The Nicotinic Acetylcholine Receptor}

The nicotinic acetylcholine receptor is an integral membrane protein that functions as a neurotransmitterdependent ion channel at the vertebrate neuromuscular junction (181). The nicotinic receptor has been most extensively studied in the Torpedo electric organ and exists as an oligomer of four polypeptide chains with masses of $40(\alpha), 50(\beta), 60(\gamma)$, and $65(\delta)$ kilodaltons (kD) with a stoichiometry of $\alpha_{2} \beta \gamma \delta$ (182). Phosphorylation of the nicotinic acetylcholine receptor has been shown to occur both in intact cells and in vitro with as many as nine phosphoserines being identified, distributed $1,1,2$, and 5 among the $\alpha, \beta, \gamma$, and $\delta$ subunits, respectively (183). Postsynaptic membranes rich in the nicotinic receptor appear to contain both endogenous protein kinase (184-186) and protein phosphatase activities (187).

The endogenous protein kinases include protein kinase $\mathrm{C}$ which phosphorylates the $\alpha$ - and $\delta$-subunits of the 
receptor on serine residues (188). In addition, an endogenous tyrosine protein kinase which phosphorylates the $\beta-, \gamma-$, and $\delta$-subunits of the receptor has been reported (188). This kinase phosphorylates a single tryosine residue on each of these subunits with stoichiometries of approximately $0.5 \mathrm{~mol}$ phosphate/mol subunit attained in postsynaptic membranes. It has also been reported that purified $\mathrm{pp} 60^{\mathrm{src}}$ of Rous sarcoma virus as well as A431 cell membranes, which are rich in EGF receptor, both specifically phosphorylate purified nicotinic acetylcholine receptor on the $\beta$-, $\gamma$-, and $\delta$-subunits (188).

The cAMP-dependent protein kinase (protein kinase A) also phosphorylates the $\gamma$ - and $\delta$-subunits of the nicotinic receptor on serine residues $(189,190)$. This phosphorylation can be completely blocked by the specific inhibitor protein of the cAMP-dependent protein kinase. Huganir and Greengard (189) have demonstrated that the $\gamma$ - and $\delta$-subunits of the purified receptor are phosphorylated by the catalytic subunit of protein kinase A to stoichiometries of 1.0 and $0.89 \mathrm{~mol}$ phosphate $/ \mathrm{mol}$ receptor, respectively. Based on amino acid sequences and subunit and substrate specificities, Huganir et al. (188) proposed the phosphorylation sites for protein kinase $A$ as serine 354 ( $\gamma$-subunit) and serine $361(\delta$ subunit). Moreover, antibodies raised against synthetic peptides encompassing the proposed phosphorylation sites inhibit phosphorylation of the receptor by protein kinase A (191).

Several recent studies have provided evidence for a functional alteration of the acetylcholine receptor when phosphorylated by protein kinase A (192-194). Two groups have demonstrated that treatment of rat skeletal muscle with forskolin, a potent activator of adenylate cyclase, leads to desensitization of nicotinic receptor function (192-194). Moreover, Huganir et al. (193) have provided direct evidence in a reconstituted system that phosphorylation of the receptor by protein kinase A increases the rate of agonist-induced desensitization of the receptor by 7 - to 8 -fold. These results provide the first direct evidence that phosphorylation regulates the function of an ion channel receptor protein.

\section{Intracellular Transport Receptors}

Eukaryotic cells internalize many macromolecules and nutrients by receptor-mediated endocytosis. The intracellular pathways of this process have been investigated in a variety of receptor systems (reviewed in Refs. 195 and 196). Upon binding of ligand, the receptors move to and cluster in specialized regions of the plasma membrane termed coated pits. These structures contain the protein clathrin which may be involved in trapping of the receptor-ligand complex. Subsequently, the coated pits invaginate to form coated vesicles which rapidly give rise to uncoated vesicles referred to as endosomes or receptosomes. The receptosome is a low $\mathrm{pH}$ compartment which promotes ligand-receptor dissociation. At this point the pathways of endocytotic receptors may diverge, with some classes of receptors being recycled back to the cell surface while others are degraded in lysosomes. The transreticular Golgi system may play a role in this sorting process (153). One of the major questions concerning receptor-mediated endocytosis is what signals are involved in triggering receptor internalization, sorting, and receptor recycling.

Recent attention has focused on phosphorylation of the receptor proteins as a mechanism of regulating their intracellular distribution. One well characterized recycling receptor, the transferrin receptor, has indeed been shown to undergo phosphorylation/dephosphorylation reactions. The transferrin receptor is an integral membrane glycoprotein composed of two identical subunits of $\mathrm{M}_{\mathrm{r}} \cong 90,000$ which are linked by a disulfide bond to form a dimer $(197,198)$. This receptor mediates the endocytosis of transferrin, resulting in cellular uptake of $\mathrm{Fe}^{2+}$. Recently, it has been reported that endocytosis of the transferrin receptor can be promoted by phorbol esters $(199,200)$. Phorbol ester treatment results in a redistribution in approximately $50 \%$ of the transferrin receptors from the plasma membrane to an endosome compartment with no loss in total receptor number. In HL60 cells this event correlates with an increase in the phosphorylation state of the transferrin receptor $(200$, 201). Although phorbol esters and transferrin induce internalization of transferrin receptors in a nonadditive fashion, transferrin itself does not promote receptor phosphorylation. This may suggest that although phosphorylation results in receptor internalization, it is not the primary signal for transferrin-induced receptor endocytosis. Recently, Davis et al. (202) have identified serine 24 as the site on the transferrin receptor phosphorylated by protein kinase $C$.

In contrast to the effects of phorbol esters, recent work has demonstrated that insulin and various growth factors can induce the redistribution of transferrin receptors from an intracellular endosome compartment to the plasma membrane $(203,204)$. In view of the observation that insulin promotes a similar redistribution of IGF-II receptors by reducing their phosphorylation state (see above), it is tempting to speculate that insulin and growth factors induce dephosphorylation of transferrin receptors leading to their enhanced cell surface expression.

Other recycling receptors may be regulated by phosphorylation events. The asialoglycoprotein receptor is phosphorylated on serine residues $(205,206)$ although the functional significance of this modification is not known. Phorbol esters have been shown to reduce the 
binding activity of low density lipoprotein (LDL) receptors (207); however receptor phosphorylation was not examined. In contrast, Kishimoto et al. (208) have demonstrated phosphorylation of the LDL receptor on serine 833 in the cytoplasmic domain by a casein kinase II-like enzyme purified from adrenal cortex. The physiological significance of this modification is unknown as mutating this serine to an alanine has no effect on the rate of LDL receptor internalization (209).

\section{Receptors Mediating Immune Function}

\section{T Lymphocyte Receptors}

The $\mathrm{T}$ cell antigen receptor is found on $\mathrm{T}$ lymphocytes where it mediates the activation of these cells by specific antigens. Clonotypic antibodies and cDNA cloning by subtractive screening methods have shown that the main core of the receptor is formed of an $\alpha(40-50 \mathrm{kD})$ - and $\beta$ (43 kD)-subunit heterodimer (reviewed in Ref. 210). However, immunoprecipitation and cross-linking experiments have suggested that the functioning receptor may involve several additional protein components. A complex of proteins termed the $\mathrm{T}_{3}$ complex has been characterized both in the human and murine systems (211214). This complex is comprised of two glycoproteins of 20-22 kD (gp21) and $26 \mathrm{kD}$ (gp26), and two nonglycosylated peptides of $25-26 \mathrm{kD}$ (p25) and $16 \mathrm{kD}(\mathrm{p} 16)$. An additional nonglycosylated subunit of $21 \mathrm{kD}$ (p21) has recently been identified in the murine system (215). Activation of the $\mathrm{T}$ cell antigen receptor complex by clonotypic antibodies or specific antigens leads to the increased hydrolysis of polyphosphoinositides, suggesting that activation of protein kinase $\mathrm{C}$ may at least in part mediate $T$ cell activation $(216,217)$. Although a biochemical role for each of the putative components of the receptor complex has not yet been established, several studies have suggested that many of these polypeptides are phosphorylated in response to $\mathrm{T}$ cell activation by specific antigens or mitogens. In human $\mathrm{T}$ lymphocytes, Cantrell et al. (218) have reported phosphorylation of two peptides of the $T_{3}$ complex $\left(M_{r}=26,000\right.$ and to a lesser extent $\left.M_{r}=21,000\right)$ upon activation of cells with phorbol esters. Samuelson et al. (215) have shown in murine $\mathrm{T}$ cell hybridomas that phorbol esters lead to phosphorylation of p25 and gp21 on serine residues. Antigen activation of these cells leads to the phosphorylation of the same gp21 subunit and a previously unidentified $21 \mathrm{kD}$ polypeptide on tyrosine residues. It has been speculated that phosphorylation of the various $T$ cell receptor complex subunits might be involved in the process of down-regulation or desensitization of the $\mathrm{T}$ cell receptor, a process induced by phorbol esters (218). Recently, the suggestion has been made (219) that the phosphorylation pattern of one of these subunits ( $p 21$, tyrosine phosphorylation) may be abnormally constitutive in a mouse model of lymphoproliferative disease. Thus, these data suggest that phosphorylation of the $\mathrm{T}$ cell antigen receptor complex may modulate several of its functions.

Another T lymphocyte-specific receptor is that which binds $\mathrm{T}$ cell growth factor (TCGF) or interleukin-2 (IL2), a $M_{r}=14,800$ glycopeptide hormone necessary for antigen- or mitogen-mediated activation of $\mathrm{T}$ cell proliferation (220). The receptor for IL-2 is a glycoprotein of $M_{r} \cong 55,000$ with a nonglycosylated amino acid core of $M_{r}=28,428$ (220). The mechanisms of signal transduction for this hormone effector system are still not completely understood. However, IL-2 has been shown to induce a redistribution of protein kinase $C$ activity (221), a property which is shared by hormones that use the phosphatidylinositol/ $\mathrm{Ca}^{++}$pathway as a transducing mechanism.

Several studies have documented that the IL-2 receptor is a phosphoprotein. Leonard et al. (222) showed that human IL-2 receptors isolated from mitogen-stimulated peripheral lymphocytes and leukemic HUT 102B2 T cells are constitutively phosphorylated. Shackelford and Trowbridge (223) have shown that treatment of activated $T$ cells or leukemic cells with phorbol esters induces the phosphorylation of the IL-2 receptor which is associated with increased expression of IL-2 receptors on the surface of these cells. More recently, Gaulton and Eardley (224) have shown that exposure of mitogen-activated splenic $\mathrm{T}$ cells to physiological concentrations of IL-2 causes rapid phosphorylation of several membrane proteins amongst which is the IL-2 receptor protein itself. By site-directed mutagenesis, Gallis et al. (225) have shown that cytoplasmic serine 247 is likely to be the site of phosphorylation of the IL-2 receptor. From these data it has been suggested that phosphorylation of the IL-2 receptor may be involved in the expression and maintenance of the receptor at the cell surface.

\section{Immunoglobulin (Ig) receptors}

Mast cells and basophils express, on their surface, specific receptors for IgE. Binding of IgE to these receptors initiates the noncytotoxic release and synthesis of a variety of chemical mediators of inflammation such as histamine and leukotrienes from these cells (226). The IgE receptor is heterotetramer composed of one $\alpha(45$ $\mathrm{kD})$-, one $\beta$ (33 kD)-, and two $\gamma$-subunits $(9 \mathrm{kD})(226)$. The $\alpha$-subunit is thought to be extracellular and serves as the ligand binding site for IgE whereas the $\beta$-subunit appears to be transmembrane. The two $\gamma$-subunits interact with the $\beta$-subunit within the cytoplasmic domain (226).

The biochemical signalling mechanisms by which $\operatorname{IgE}$ 
initiates its effects are still poorly understood; nonetheless, phosphorylation of the $\mathrm{IgE}$ receptor has been examined as a possible control mechanism for IgE-mediated effects. Hempstead et al. $(227,228)$ have reported that in normal rat mast cells, the $\alpha$ - and $\beta$-subunits of the receptor are constitutively phosphorylated. Antigen activation of these cells results in increased phosphorylation of the $\alpha$-subunit whereas the $\beta$-subunit phosphorylation is unaltered. The increase in $\alpha$-subunit phosphorylation occurs within the time scale of cell activation leading to the hypothesis that this covalent modification is a primary event in receptor action. In contrast, Metzger and colleagues $(229,230)$, using basophilic leukemia cells, observed phosphorylation of the $\beta$ - and $\gamma$-subunits of the $\operatorname{IgE}$ receptor but no phosphorylation of the $\alpha$ subunit. In these cells, antigen activation results in increased phosphorylation of the $\beta$-subunit whereas the $\gamma$ subunit phosphorylation is decreased. In light of these controversial findings, it is clear that more work will be necessary to define a functional role for IgE receptor phosphorylation.

Polymeric IgA, the major immunoglobulin in external secretions, is synthesized in plasma cells of various mucosal tissues as well as exocrine glands (231). Receptors for IgA are synthesized by a variety of epithelial cells, including hepatocytes, and mediate the secretion of polyIgA via receptor-mediated transport across the epithelia (232). In hepatocytes, the mature form of the receptor $(120 \mathrm{kD})$ arises from two intermediate precursors, a 105 $\mathrm{kD}$ initial precursor which becomes glycosylated to a 116 $\mathrm{kD}$ secondary form. The final maturation of the $116 \mathrm{kD}$ precursor to the mature $120 \mathrm{kD}$ form is associated with phosphorylation of the intracellular domain of the receptor on serine residues (233). Whereas this active form of the IgA receptor appears to be phosphorylated, the biological significance of this phosphorylation is still not understood. One possibility is that it is involved in the sorting patterns and intracellular processing of the receptor protein (233).

\section{Conclusions}

A rapidly expanding body of literature now indicates that the functionality and/or cellular distribution of cell surface receptors for hormones, drugs, neurotransmitters, and growth factors can be regulated by phosphorylation. In many instances where phosphorylation directly alters receptor function, this appears to be in a negative direction. Thus, receptor phosphorylation may result in decreased agonist ligand binding or a diminished ability of the receptor to interact with its biochemical effector. In some cases, the enzymatic activity of a receptor molecule may be inhibited. In contrast, autophosphorylation of the tyrosine kinase receptors may result in increased enzymatic activity and enhanced receptor function. In those receptor systems which exhibit internalization and recycling phenomena, phosphorylation appears to result in enhanced receptor internalization. The biological role for this internalization event may be quite varied and system specific. In some cases, the consequence of receptor internalization may be dephosphorylation and resensitization, whereas in others the result is enhanced endocytosis of a specific ligand. Future work in this rapidly growing field will undoubtedly focus on identifying a role for phosphorylation in other receptor systems, characterizing the protein kinases and phosphatases involved, and elucidating the molecular mechanisms by which phosphorylation produces its functional effects.

\section{Acknowledgment}

We wish to thank Mary M. Holben for her expert secretarial help in the preparation of this manuscript.

\section{References}

1. Krebs EG, Beavo JA 1979 Phosphorylation-dephosphorylation of enzymes. Annu Rev Biochem 48:923

2. Flockhart DA, Corbin JD 1982 Regulatory mechanisms in the control of protein kinases. CRC Crit Rev Biochem 12:133

3. Gilman, AG $1984 \mathrm{G}$ proteins and dual control of adenylate cyclase. Cell 36:577

4. Stryer, L, Bourne HR 1986 G-Proteins: a Family of signal transducers. Annu Rev Cell Biol 2:391

5. Spiegel, AM 1987 Signal transduction by guanine nucleotide binding proteins. Mol Cell Endocrinol 49:1

6. Sibley, DR, Lefkowitz RJ 1985 Molecular mechanisms of receptor desensitization using the $\beta$-adrenergic receptor-coupled adenylate cyclase system as a model. Nature $317: 124$

7. Hertel C, Perkins JP 1984 Receptor-specific mechanisms of desensitization of $\beta$-adrenergic receptor function. Mol Cell Endocrinol 37:245

8. Harden TK 1983 Agonist-induced desensitization of the $\beta$-adrenergic receptor-linked adenylate cyclase. Pharmacol Rev $36: 5$

9. Kassis S, Fishman PH 1982 Different mechanisms of desensitization of adenylate cyclase by isoproterenol and prostaglandin $E_{1}$ in human fibroblasts: role of regulatory components in desensitization. J Biol Chem 257:5312

10. Garrity MJ, Andreasen TJ, Storm DR, Robertson RP 1983 Prostaglandin E-induced heterologous desensitization of hepatic adenylate cyclase: consequences on the guanyl nucleotide regulatory complex. J Biol Chem 258:8692

11. Kirchik HJ, Iyengar R, Birnbaumer L 1983 Human chorionic gonadotropin-induced heterologous desensitization of adenylate cyclase from highly lutenized rat ovaries: attenuation of regulatory $\mathrm{N}_{8}$ component activity. Endocrinology 113:1638

12. Rich KA, Codina J, Floyd G, Sekura R, Hildebrandt JD, Iyengar R 1984 Glucagon-induced heterologous desensitization of the MDCK cell adenylate cyclase. J Biol Chem 259:7893

13. Briggs MM, Stadel JM, Iyengar R, Lefkowitz RJ 1983 Functional modification of the guanine nucleotides regulatory protein after desensitization of turkey erythrocytes by catecholamines. Arch Biochem Biophys 224:142

14. Stadel JM, Nambi P, Shorr RGL, Sawyer DF, Caron MG, Lefkowitz RJ 1983 Catecholamine-induced desensitization of turkey erythrocyte adenylate cyclase is associated with phosphorylation of the $\beta$-adrenergic receptor. Proc Natl Acad Sci USA 80:3173

15. Sibley DR, Peters JR, Nambi P, Caron MG, Lefkowitz RJ 1984 Desensitization of turkey erythrocyte adenylate cyclase: $\beta$-Adre- 
nergic receptor phosphorylation is correlated with attenuation of adenylate cyclase activity. J Biol Chem 259:9742

16. Sibley DR, Daniel KD, Strader CD, Lefkowitz RJ 1987 Phosphorylation of the $\beta$-adrenergic receptor in intact cells: relationship to heterologous and homologous mechanisms of adenylate cyclase desensitization. Arch Biochem Biophys 258:24

17. Stadel JM, Rebar R, Shorr RGL, Nambi P, Crooke ST 1986 Biochemical characterization of phosphorylated $\beta$-adrenergic receptors from catecholamine-desensitized turkey erythrocytes. Biochemistry 25:3719

18. Benovic JL, Pike LJ, Cerione RA, Staniszewski C, Yoshimasa T, Codina J, Caron MG, Lefkowitz RJ 1985 Phosphorylation of the mammalian $\beta$-adrenergic receptor by cyclic AMP-dependent protein kinase. J Biol Chem 260:7094

19. Sibley DR, Nambi P, Peters JR, Lefkowitz RJ 1984 Phorbol diesters promote $\beta$-adrenergic receptor phosphorylation and adenylate cyclase desensitization in duck erythrocytes. Biochem Biophys Res Commun 121:973

20. Kelleher DJ, Pessin JE, Ruoho AE, Johnson GL 1984 Phorbol ester induces desensitization of adenylate cyclase and phosphorylation of the $\beta$-adrenergic receptor in turkey erythrocytes. Proc Natl Acad Sci USA 81:4316

21. Bouvier M, Leeb-Lundberg LMF, Benovic JL, Caron MG, Lefkowitz RJ 1986 Regulation of adrenergic receptor function by phosphorylation. II. Effects of agonist occupancy on phosphorylation of $\alpha_{1}$ - and $\beta_{2}$-adrenergic receptors by protein kinase $C$ and the cyclic AMP-dependent protein kinase. J Biol Chem 262:3106

22. Dixon RAF, Kobilka BK, Strader DJ, Benovic JL, Dohlman HG Frielle T, Bolanowski MA, Bennett CD, Rands E, Diehl RE, Mumford RA, Slater EE, Sigal IS, Caron MG, Lefkowitz RJ, Strader CD 1986 Cloning of the gene and cDNA for mammalian $\beta$-adrenergic receptor and homology with rhodopsin. Nature $321: 75$

23. Glass DB, Krebs EG 1980 Protein phosphorylation catalyzed by cyclic AMP-dependent and cyclic GMP-dependent protein kinases. Annu Rev Pharmacol Toxicol 20:363

24. Kishimoto A, Nishiyama K, Nakanishi H, Vratsuji NH, Takayama Y, Nishizuka Y 1985 Studies on the phosphorylation of myelin basic protein by protein kinase $C$ and adenosine $3^{\prime}: 5^{\prime}$. monophosphate dependent protein kinase. J Biol Chem 260:12492

25. Limas CJ, Limas C 1985 Carbachol induces desensitization of cardiac $\beta$-adrenergic receptors through muscarinic $\mathbf{M}_{1}$ receptors. Biochem Biophys Res Commun 128:699

26. Sibley DR, Strasser RH, Caron MG, Lefkowitz RJ 1985 Homologous desensitization of adenylate cyclase is associated with phosphorylation of the $\beta$-adrenergic receptor. J Biol Chem 260:3883

27. Strasser RH, Sibley DR, and Lefkowitz RJ 1986 A novel catecholamine-activated adenosine cyclic $3^{\prime}, 5^{\prime}$ monophosphate independent pathway for $\beta$-adrenergic receptor phosphorylation in wild-type and mutant $S_{49}$ lymphoma cells: mechanism of homologous desensitization of adenylate cyclase. Biochemistry 25:1371

28. Benovic JL, Strasser RH, Caron MG, Lefkowitz RJ $1986 \beta$ Adrenergic receptor kinase: identification of a novel protein kinase that phosphorylates the agonist-occupied form of the receptor. Proc Natl Acad Sci USA 83:2797

29. Benovic JL, Mayor Jr F, Somers RL, Caron MG, Lefkowitz RJ 1986 Light-dependent phosphorylation of rhodopsin by $\beta$-adrenergic receptor kinase. Nature 322:869

30. Benovic JL, Mayor F, Staniszewski C, Lefkowitz RJ, Caron MG 1987 Purification and characterization of the $\beta$-adrenergic receptor kinase. J Biol Chem 262:9026

31. Strasser RH, Benovic JL, Caron MG, Lefkowitz RJ $1986 \beta$ agonist- and prostaglandin $\mathrm{E}_{1}$-induced translocation of the $\beta$ adrenergic receptor kinase: evidence that the kinase may act on multiple adenylate cyclase-coupled receptors. Proc Natl Acad Sci USA 83:6362

32. Sibley DR, Strasser RH, Benovic JL, Daniel K, Lefkowitz RJ 1986. Phosphorylation/dephosphorylation of the $\beta$-adrenergic receptor regulates its functional coupling to adenylate cyclase and subcellular distribution. Proc Natl Acad Sci USA 83:9408

33. Nishizuka Y 1984 The role of protein kinase $C$ in cell surface signal transduction and tumour promotion. Nature 308:693
34. Sibley DR, Jeffs RA, Daniel K, Nambi P, Lefkowitz RJ 1986 Phorbol diester treatment promotes enhanced adenylate cyclase activity in frog erythrocytes. Arch Biochem Biophys 244:373

35. Bell JD, Brunton LL 1986 Enhancement of adenylate cyclase activity in S49 cells by phorbol esters. J Biol Chem 260:2625

36. Cronin MJ, Canonico PO 1985 Tumor promoters enhance basal and growth hormone releasing factor stimulated cAMP levels in anterior pituitary cells. Biochem Biophys Res Commun 129:404

37. Sulakhe PV, Johnson DD, Phan NT, Wilcons R 1985 Phorbol ester inhibits myoblast fusion and activates $\beta$-adrenergic receptorcoupled adenylate cyclase. FEBS Lett 186:281

38. Hollingsworth EB, Ukena D, Daly JW 1986 The protein kinase C activator phorbol-12-myristate-13-acetate enhances cyclic AMP accumulation in pheochromocytoma cells. FEBS Lett 196:131

39. Johnson JA, Goka TJ, Clark RB 1986 Phorbol ester-induced augmentation and inhibition of epinephrine-stimulated adenylate cyclase in S49 lymphoma cells. J Cyclic Nucleotide Res 151:199

40. Naghshineh S, Noguchi N, Huang KP, Londos C 1986 Activation of adipocyte adenylate cyclase by protein kinase $\mathrm{C}$. J Biol Chem 261:14534

41. Yoshimasa T, Sibley DR, Bouvier M, Lefkowitz RJ, Caron MG 1987 Cross-talk between second messenger generating systems: phorbol esters induce phosphorylation of the catalytic unit of adenylate cyclase activity and enhancement of its activity. Nature 327:67

42. Berridge MJ, Irvine RF 1984 Inositol triphosphate, a novel second messenger in cellular signal transduction. Nature 312:315

43. Cotecchia S, Leeb-Lundberg LMF, Hagen P-O, Lefkowitz RJ, Caron MG 1985 Phorbol ester effects on $\alpha_{1}$-adrenoceptor binding and phosphatidylinositol metabolism in cultured vascular smooth muscle cells. Life Sci 37:2389

44. Leeb-Lundberg LMF, Cotecchia S, Lomasney J, DeBernardis JF, Lefkowitz RJ, Caron MG 1985 Phorbol esters promote $\alpha_{1}$-adrenergic receptor phosphorylation and receptor uncoupling from inositol phospholipid metabolism. Proc Natl Acad Sci USA $82: 5651$

45. Leeb-Lundberg LMF, Cottechia S, DeBlasi A, Caron MG, Lefkowitz RJ 1987 Regulation of adrenergic receptor function by phosphorylation. I. Agonist-promoted desensitization and phosphorylation of $\alpha_{1}$-adrenergic receptors coupled to inositol phospholipid metabolism in DDT 1 MF-2 smooth muscle cells. J Biol Chem 262:3098

46. Vicentini LM, Virgilo, FD, Ambrosini A, Pozzan T, Meldolesi J 1985 Tumor promoter 12-myristate, 13-acetate inhibits phosphinositide hydrolysis and cytosolic $\mathrm{Ca}^{2+}$ rise induced by the activation of muscarinic receptors in PC 12 cells. Biochem Biophys Res Commun 127:310

47. Masters SB, Quinn MT, Brown JH 1985 Agonist-induced desensitization of muscarinic receptor-mediated calcium efflux without concomitant desensitization of phosphoinositide hydrolysis. Mol Pharmacol 27:325

48. Orellana SA, Solski PA, Brown JH 1985 Phorbol ester inhibits phosphoinostide hydrolysis and calcium mobilization in cultured astrocytoma cells. J Biol Chem 260:5236

49. Harden TK, Petch LA, Traynelis SF, Waldo GL 1985 Agonistinduced alteration in the membrane form of muscarinic cholinergic receptors. J Biol Chem 260:13060

50. Liles WC, Hunter DD, Meier KE, Nathanson NM 1986 Activation of protein kinase $\mathrm{C}$ induces rapid internalization and subsequent degradation of muscarinic acetylcholine receptors in neuroblastoma cells. J Biol Chem 261:5307

51. Kwatra MM, Hosey MM 1986 Phosphorylation of the cardiac muscarinic receptor in intact chick heart and its regulation by a muscarinic agonist. J Biol Chem 261:12429

52. Stryer L 1986 Cyclic GMP cascade of vision. Annu Rev Neurosci 9:87

53. Kuhn H, Dreyer WJ 1972 Light-dependent phosphorylation of rhodopsin by ATP. FEBS Lett 20:1

54. Kuhn H, Cook JH, Dreyer WJ 1973 Phosphorylation of rhodopsin in bovine photoreceptor membranes: a dark reaction after illumination. Biochemistry 12:2495 
55. Kuhn H 1978 Light-regulated binding of rhodopsin kinase and other proteins to cattle photoreceptor membranes. Biochemistry $17: 4389$

56. Kuhn H, Hargrave PA 1981 Light-induced binding of guanosine triphosphatase to bovine photoreceptor membranes: effect of limited proteolysis of the membranes. Biochemistry 20:2410

57. Bownds D, Dawes J, Miller J, Stahlman M 1972 Phosphorylation of frog photoreceptor membranes induced by light. Nature 237:125

58. Hargrave PA, Fong SL, McDowell JH, Mas MT, Curtis DR, Wang JK, Juszcak E, Smith DP 1980 The partial primary structure of bovine rhodopsin and its topography in the retinal rod cell disc membrane. Neurochem Intern 1:231

59. Kuhn H, Hall SW, Wilden U 1984 Light-induced binding of 48 $\mathrm{kDa}$ protein to photoreceptor membranes is highly enhanced by phosphorylation of rhodopsin. FEBS Lett 176:473

60. Wilden U, Hall SW, Kuhn H 1986 Phosphodiesterase activation by photoexcited rhodopsin is quenched when rhodopsin is phosphorylated and binds the intrinsic $48-\mathrm{kDa}$ protein of rod outer segments. Proc Natl Acad Sci USA 83:1174

61. Czech MP 1985 The nature and regulation of the insulin receptor: structure and function. Annu Rev Physiol 47:357

62. Kahn CR 1985 The molecular mechanism of insulin action. Annu Rev Med 36:429

63. Ullrich A, Bell JR, Chen EY, Herrera R, Petruzzelli LM, Dull TJ, Gray A, Coussens L, Liao Y-C, Tsubokawa M, Mason A, Seeburg PH, Grunfeld C, Rosen OM, Ramachandran J 1985 Human insulin receptor and its relationship to the tyrosine kinase family of oncogenes. Nature 313:756

64. Ebina Y, Ellis L, Jarnigan, Edery M, Graf L, Clauser E, Ou, J-h, Masiarz F, Kan YW, Goldfine ID, Roth RA, Rutter WJ 1985 The human insulin receptor cDNA: the structural basis for hormoneactivated transmembrane signalling. Cell 40:747

65. Kasuga M, Karlsson FA, Kahn CR 1981 Insulin stimulates the phosphorylation of the 95,000 dalton subunit of its own receptor. Science 215:185

66. Kasuga M, Zick Y, Blith, Karlsson FA, Haring HU, Kahn CR 1982 Insulin stimulation of phosphorylation of the $\beta$ subunit of the insulin receptor. J Biol Chem 257:9891

67. Haring H-U, Kasuga M, Kahn CR 1982 Insulin receptor phosphorylation in intact adipocytes and in a cell-free system. Biochem Biophys Res Commun 108:1538

68. Gazzano H, Kowalski A, Fehlmann M, Von Obberghen E 1983 Two different protein kinase activities are associated with the insulin receptor. Biochem $\mathrm{J} 216: 575$

69. Takayama S, White MF, Lauris V, Kahn CR 1984 Phorbol esters modulate insulin receptor phosphorylation and insulin action in cultured hepatoma cells. Proc Natl Acad Sci USA 81:7797

70. Haring H-U, Kasuga M, White MF, Crettaz M, Kahn CR 1984 Phosphorylation and dephosphorylation of the insulin receptor: evidence against an intrinsic phosphatase activity. Biochemistry 23:3298

71. Pang DT, Sharma BR, Shafer JA 1985 Predominance of tyrosine phosphorylation of insulin receptors during the initial response of intact cells to insulin. J Biol Chem 260:7131

72. White MF, Takayama S, Kahn CR 1985 Differences in the sites of phosphorylation of the insulin receptor in vivo and in vitro. $\mathrm{J}$ Biol Chem 260:9470

73. Jacobs S, Cuatrecasas P 1986 Phosphorylation of receptors for insulin and insulin-like growth factor I. J Biol Chem 261:934

74. Yu K-T, Czech MP 1986 Tyrosine phosphorylation of insulin receptor $\beta$ subunit activates the receptor tyrosine kinase in intact H-35 hepatoma cells. J Biol Chem 261:4715

75. Stadtmauer L, Rosen OM 1986 Increasing the cAMP content of IM-9 cells alters the phosphorylation state and protein kinase activity of the insulin receptor. J Biol Chem 261:3402

76. Stadtmauer L, Rosen OM 1986 Phosphorylation of synthetic insulin receptor peptides by the insulin receptor kinase and evidence that the preferred sequence containing Tyr-1150 is phosphorylated in vitro. J Biol Chem 261:10000

77. Pike LJ, Krebs EG 1986 Protein tyrosine kinase activity of hormone and growth factor receptors. In: Conn PM (ed) The Receptors. Academic Press, New York, vol 3:93-134
78. White MF, Haring H-U, Kasuga M, Kahn CR 1984 Kinetic properties and sites of autophosphorylation of the partially purified insulin receptor from hepatoma cells. J Biol Chem 259:255

79. Petruzzelli L, Herrera R, Rosen OM 1984 Insulin receptor is an insulin-dependent tyrosine protein kinase: copurification of insulin-binding activity and protein kinase activity to homogeneity from human placenta. Proc Natl Acad Sci USA 81:3327

80. Roth RA, Cassell DJ 1983 Insulin receptor: evidence that it is a protein kinase. Science 219:299

81. Van Obberghen E, Rossi B, Kowalski A, Gazzano H, Ponzio G 1983 Receptor-mediated phosphorylation of the hepatic insulin receptor: evidence that the $M_{r} 95,000$ receptor subunit is its own kinase. Proc Natl Acad Sci USA 88:945

82. Shia MA, Pilch PF 1983 The $\beta$ subunit of the insulin receptor is an insulin-activated protein kinase. Biochemistry 22:717

83. Kasuga M, Zick Y, Blithe DL, Crettaz M, Kahn, Kahn CR 1982 Insulin stimulates tyrosine phosphorylation of the insulin receptor in a cell-free system. Nature 298:667

84. Zick Y, Kasuga M, Kahn CR, Roth J 1983 Characterization of insulin-mediated phosphorylation of the insulin receptor in a cellfree system. J Biol Chem 258:75

85. Yu K-T, Czech MP 1984 Tyrosine phosphorylation of the insulin receptor $\beta$ subunit activates the receptor-associated tyrosine $\mathrm{ki}$ nase activity. J Biol Chem 259:5277

86. Rosen OM, Herrera R, Olowe Y, Petruzzelli LM, Cobb MH 1983 Phosphorylation activates the insulin receptor tyrosine protein kinase. Proc Natl Acad Sci USA 80:3237

87. Kwok YC, Nemenoff RA, Powers AC, Avruch J 1986 Kinetic properties of the insulin receptor tyrosine protein kinase: activation through an insulin-stimulated tyrosine-specific, intramolecular autophosphorylation. Arch Biochem Biophys 244:102

88. Klein HH, Freidenberg GR, Kladde M, and Olefsky JM 1986 Insulin activation of insulin receptor tyrosine kinase in intact rat adipocytes. J Biol Chem 261:4691

89. Herrera R, Rosen OM 1986 Autophosphorylation of the insulin receptor in vitro. $\mathrm{J}$ Biol Chem 261:11980

90. Herrera R, Petruzzelli L, Thomas N, Bramson HN, Kaiser ET, Rosen OM 1985 An antipeptide antibody that specifically inhibits insulin receptor autophosphorylation and protein kinase activity. Proc Natl Acad Sci USA 82:7899

91. Tornqvist HE, Pierce MW, Frackelton R, Nemenoff RA, Avruch $\mathrm{J} 1987$ Identification of insulin receptor tyrosine resdues autophosphorylated in vitro. J Biol Chem 262:10212

92. Ellis L, Clauser E, Morgan DO, Edery M, Roth RA, Rutter WA 1986 Replacement of insulin receptor tyrosine residues 1162 and 1163 compromises insulin-stimulated kinase activity and uptake of 2-deoxyglucose. Cell 45:721

93. Pessin JE, Gitomer W, Oka Y, Oppenheimer CL, Czech MP 1983 $\beta$-Adrenergic regulation of insulin and epidermal growth factor receptors in rat adipocytes. J Biol Chem 258:7386

94. Haring H, Kirsch D, Obermaier B, Ermel B, Machicao F 1986 Decreased tyrosine kinase activity of insulin receptor isolated from rat adipocytes rendered insulin-resistant by catecholamine treatment in vitro. Biochem $\mathrm{J} 234: 59$

95. Jacobs S, Sahyoun NE, Saltiel AR, Cuatrecasas 1983 Phorbol esters stimulate the phosphorylation of receptors for insulin and somatomedin C. Proc Natl Acad Sci USA 80:6211

96. Haring H, Kirsch D, Obermaier B, Ermel B, Machicao F 1986 Tumor-promoting phorbol esters increase the $K_{m}$ of the ATP. binding site of the insulin receptor kinase from rat adipocytes. $J$ Biol Chem 261:3869

97. Bollag GE, Roth RA, Beaudoin J, Mochly-Rosen D, Koshland Jr DE 1986 Protein kinase C directly phosphorylates the insulin receptor in vitro and reduces its protein-tyrosine kinase activity. Proc Natl Acad Sci USA 83:5822

98. Arsenis G, Livingston JN 1986 Alterations in the tyrosine kinase activity of the insulin receptor produced by in vitro hyperinsulinemia. J Biol Chem 261:147

99. Blake AD, Hayes NS, Slater EE, Strader CD 1987 Insulin receptor desensitization correlates with attenuation of tyrosine kinase activity but not of receptor endocytosis. Biochem J 245:357

100. Morgan DO, Jarnigan K, Roth RA 1986 Purification and char- 
acterization of the receptor for insulin-like growth factor I. Biochemistry $25: 5560$

101. Ullrich A, Gray A, Tam AW, Yang-Feng T, Tsubokawa M, Collins C, Henzel W, Le Bon T, Kathuria S, Chen E, Jacobs, Francke U, Ramachandran J, Fujita-Yamaguchi Y 1986 Insulin-like growth factor I receptor primary structure: comparison with insulin receptor suggests structural determinants that define functional specificity. EMBO J 5:2503

102. Jacobs S, Kull Jr F, Earp HS, Svoboda ME, Van Wyk JJ, Cuatrecasas P 1983 Somatomedin-C stimulates the phosphorylation of the $\beta$-subunit of its own receptor. J Biol Chem 258:9581

103. Rubin JB, Shia MA, Pilch PF 1983 Stimulation of tyrosinespecific phosphorylation in vitro by insulin-like growth factor I. Nature 305:438

104. Zick Y, Sasaki N, Rees-Jones RW, Grunberger G, Nissley SP, Rechler MM 1984 Insulin-like growth factor-I (IGF-I) stimulates tyrosine kinase activity in purified receptors from a rat liver cell line. Biochem Biophys Res Commun 119:6

105. Sasaki N, Rees-Jones RW, Zick Y, Nissley SP, Rechler MM 1985 Characterization of insulin-like growth factor I-stimulated tyrosine kinase activity associated with the $\beta$-subunit of type I insulinlike growth factor receptors of rat liver cells. J Biol Chem 260:9793

106. Catanese VM, Grigorescu F, King GL, Kahn CR 1986 The human erythrocyte insulin-like growth factor I receptor: characterization and demonstration of ligand-stimulated autophosphorylation. $J$ Clin Endocrinol Metab 62:692

107. Yu K-T, Peters MA, Czech MP 1986 Similar control mechanisms regulate the insulin and type I insulin-like growth factor receptor kinases. J Biol Chem 261:11341

108. Fouis M, Thomopoulos P, Postel-Vinay M, Testa U, Guyda HJ, Posner BI 1984 The effect of phorbol esters on the receptors for insulin-like peptides (ILAs). Mol Physiol 5:123

109. Oppenheimer CL, Czech MP 1983 Purification of the type II insulin-like growth factor receptor from rat placenta. J Biol Chem 258:8539

110. Corvera S, Whitehead RE, Mottola C, Czech MP 1986 The insulin-like growth factor II receptor is phosphorylated by a tyrosine kinase in adipocyte plasma membranes. J Biol Chem 261:7675

111. Oka Y, Czech MP 1986 The type II insulin-like growth factor receptor is internalized and recycles in the absence of ligand. $J$ Biol Chem 261:9090

112. Oka Y, Mottola C, Oppenheimer CL, Czech MP 1984 Insulin activates the appearance of insulin-like growth factor II receptors on the adipocyte cell surface. Proc Natl Acad Sci USA 81:4028

113. Oka Y, Rozek LM, Czech MP 1985 Direct demonstration of rapid insulin-like growth factor II receptor internalization and recycling in rat adipocytes. $J$ Biol Chem 260:9435

114. Corvera S, Czech MP 1985 Mechanism of insulin action on membrane protein recycling: a selective decrease in the phosphorylation state of insulin-like growth factor II receptors in the cell surface membrane. Proc Natl Acad Sci USA 82:7314

115. Carpenter G 1983 The biochemistry and physiology of the receptor-kinase for epidermal growth factor. Mol Cell Endocrinol 31:1

116. Cohen S, Fava RA, Sawyer ST 1982 Purification and characterization of epidermal growth factor receptor/protein kinase from normal mouse liver. Proc Natl Acad Sci USA 79:6237

117. Sefton BM, Hunter T 1984 Tyrosine protein kinases. Adv Cyclic Nucleotide Protein Phosphorylation Res 18:195

118. Hunter T, Cooper JA 1985 Protein-tyrosine kinases. Annu Rev Biochem 54:897

119. Ullrich A, Coussens L, Hayflick JS, Dull TJ, Gray A, Tam AW, Lee J, Yarden LY, Liebemann TA, Schlessinger J, Downward J, Mayes ELV, Whittle N, Waterfield MD, Seeburg PH 1984 Human epidermal growth factor receptor cDNA sequence and aberrant expression of the amplified gene in A431 epidermoid carcinoma cells. Nature 309:418

120. Xu Y-h, Ishii S, Clark AJL, Sullivan M, Wilson RK, Ma DP, Roe BA, Merlino GT, Pastan I 1984 Human epidermal growth factor receptor cDNA is homologous to a variety of RNAs overproduced in A431 carcinoma cells. Nature 309:806

121. Lin CR, Chen WS, Kruiger W, Stolarsky LS, Weber W, Evans
RM, Verma IM, Gill GN, Rosenfeld MG 1984 Expression of cloning of human EGF receptor complementary DNA: gene amplification and three related messenger RNA products in A431 cells. Science $25: 843$

122. Downward J, Yarden Y, Mayes E, Scrace G, Totty N, Stockwell P, Ullrich A, Schlessinger J, Waterfield MD 1984 Close similarity of epidermal growth factor receptor and v-erb-B oncogene protein sequences. Nature 307:521

123. Hunter T, Cooper JA 1981 Epidermal growth factor induces rapid tyrosine phosphorylation of proteins in A431 human tumor cells. Cell 24:741

124. Iwashita S, Fox CF 1984 Epidermal growth factor and potent phorbol tumor promoters induce epidermal growth factor receptor phosphorylation in a similar but distinctively different manner in human epidermoid carcinoma A431 cells. J Biol Chem 259:2559

125. Davis RJ, Czech MP 1984 Tumor-promoting phorbol diesters mediate phosphorylation of the epidermal growth factor receptor. J Biol Chem 259:8545

126. Downward J, Parker P, Waterfield MD 1984 Autophosphorylation sites on the epidermal growth factor receptor. Nature 311:483

127. Weber W, Bertics PJ, Gill GN 1984 Immunoaffinity purification of the epidermal growth factor. J Biol Chem 259:14631

128. Bertics PJ, Weber W, Cochet C, Gill GN 1985 Regulation of the epidermal growth factor receptor by phosphorylation. J Biol Chem 29:195

129. Bertics PJ, Gill GN 1985 Self-phosphorylation enhances the protein tyrosine kinase activity of the epidermal growth factor receptor. J Biol Chem 260:14642

130. Cassel D, Pike LJ, Grant GA, Krebs EG, Glaser L 1983 Interaction of epidermal growth factor-dependent protein kinase with endogenous membrane proteins and soluble peptide substrates. J Biol Chem 258:2945

131. Downward J, Waterfield MD, Parker PJ 1985 Autophosphorylation and protein kinase $\mathrm{C}$ phosphorylation of the epidermal growth factor receptor. J Biol Chem 260:14538

132. Gullick WJ, Downward J, Waterfield MD 1985 Antibodies to the autophosphorylation sites of the epidermal growth factor receptor protein-tyrosine kinase as probes of structure and function. EMBO J 4:2869

133. Yarden Y, Schlessinger J 1987 Self-phosphorylation of epidermal growth factor receptor: evidence for a model of intramolecular allosteric activation. Biochemistry 26:1434

134. Cochet C, Gill GN, Meisenhelder J, Cooper JA, Hunter T 1984 C-Kinase phosphorylates the epidermal growth factor receptor and reduces its epidermal growth factor stimulated tyrosine protein kinase activity. J Biol Chem 259:2553

135. Sawyer ST, Cohen S 1981 Enhancement of calcium uptake and phosphatidylinositol turnover by epidermal growth factor in A431 cells. Biochemistry 20:6280

136. Pike LJ, Eakes AT 1987 Epidermal growth factor stimulates the production of phosphatidylinositol monophosphate and the breakdown of polyphosphoinositides in A431 cells. J Biol Chem 262:1644

137. Bell RM 1986 Protein kinase $C$ activation by diacylglycerol second messengers. Cell 45:631

138. Lee L-S, Weinstein IB 1978 Tumor-promoting phorbol esters inhibit binding of epidermal growth factor to cellular receptors. Science 202:313

139. Lee L-S, Weinstein IB 1979 Mechanism of tumor promoter inhibition of cellular binding of epidermal growth factor. Proc Natl Acad Sci USA 76:5168

140. Brown KD, Dicker P, Rozengurt E 1979 Inhibition of epidermal growth factor binding to surface receptors by tumor promotors. Biochem Biophys Res Commun 86:1037

141. Shoyab M, DeLarco JE, Todaro GJ 1979 Biologically active phorbol esters specifically alter affinity of epidermal growth factor membrane receptors. Nature 279:387

142. Magun BE, Matrisian LM, Bowden GT 1980 Epidermal growth factor. J Biol Chem 255:6373

143. Salomon DS 1981 Inhibition of epidermal growth factor binding to mouse embryonal carcinoma cells by phorbol esters mediated by specific phorbol ester receptors. J Biol Chem 256:7958 
144. King AC, Cuatrecasas $P 1982$ Resolution of high and low affinity epidermal growth factor receptors. J Biol Chem 257:3053

145. Hunter T, Ling N, Cooper JA 1984 Protein kinase C phosphorylation of the EGF receptor at a threonine residue close to the cytoplasmic face of the plasma membrane. Nature 311:480

146. Chinkers M, Garbers DL 1984 Phorbol ester-induced threonine phosphorylation of the human epidermal growth factor receptor occurs within the EGF binding domain. Biochem Biophys Res Commun 123:618

147. Davis RJ, Czech MP 1985 Tumor-promoting phorbol diesters cause the phosphorylation of epidermal growth factor receptors in normal fibroblasts at threonine-654. Proc Natl Acad Sci USA 82:1974

148. Friedman BA, Frackelton Jr AR, Ross AH, Connors JM, Fujiki H, Sugimura T, Rosner MR 1984 Tumor promoters block tyrosine-specific phosphorylation of the epidermal growth factor receptor. Proc Natl Acad Sci USA 81:3034

149. Davis RJ, Czech MP 1986 Inhibition of the apparent affinity of the epidermal growth factor receptor caused by phorbol diesters correlates with phosphorylation of threonine-654 but not other sites on the receptor. Biochem J 233:435

150. Lin CR, Chen WS, Lazar CS, Carpenter CD, Gill GN, Evans RM, Rosenfeld MG 1986 Protein kinase C phosphorylation at Thr 654 of the unoccupied EGF receptor and EGF binding regulate functional receptor loss by independent mechanisms. Cell 44:839

151. Beguinot L, Hanover JA, Ito S, Richert ND, Willingham MC, Pastan I 1985 Phorbol esters induce transient internalization without degradation of unoccupied epidermal growth factor receptors. Proc Natl Acad Sci USA 82:2774

152. Fearn JC, King AC 1985 EGF receptor affinity is regulated by intracellular calcium and protein kinase C. Cell 40:991

153. Pastan I, Hanover J, Willingham M 1985 The cellular entry of EGF and transferrin: a problem in intracellular sorting. Curr Top Cell Regul 26:17

154. King CS, Cooper JA 1986 Effects of protein kinase C activation after epidermal growth factor binding on epidermal growth factor receptor phosphorylation. J Biol Chem 261:10073

155. Sunada H, Magun BE, Mendelsohn J, MacLeod CL 1986 Monoclonal antibody against epidermal growth factor receptor is internalized without stimulating receptor phosphorylation. Proc Natl Acad Sci USA 83:3825

156. Chinkers M, Garbers DL 1986 Suppression of protein tyrosine kinase activity of the epidermal growth factor receptor by epidermal growth factor. J Biol Chem 261:8295

157. Rozengurt E, Brown KD, Pettican P 1980 Vasopressin inhibition of epidermal growth factor binding to cultured mouse cells. J Biol Chem 256:716

158. Rozengurt E, Collins M, Brown KD, Pettican P 1982 Inhibition of epidermal growth factor binding to mouse cultured cells by fibroblast-derived growth factor. J Biol Chem 257:3680

159. Wharton W, Leof E, Pledger WJ, O'Keefe EJ 1982 Modulation of the epidermal growth factor receptor by platelet-derived growth factor and choleragen: effects on mitogenesis. Proc Natl Acad Sci USA 79:5567

160. Collins MKL, Sinnett-Smith JW, Rozengurt E 1983 Plateletderived growth factor treatment decreases the affinity of the epidermal growth factor receptors of Swiss 3T3 cells. J Biol Chem 258:11689

161. Brown KD, Blay J, Irvine RF, Heslop JP, Berridge MJ 1984 Reduction of epidermal growth factor receptor affinity by heterologous ligands: evidence for a mechanism involving the breakdown of phosphoinositides and the activation of protein kinase C. Biochem Biophys Res Commun 123:377

162. Davis RJ, Czech MP 1985 Platelet-derived growth factor mimics phorbol diester action on epidermal growth factor receptor phosphorylation at threonine-654. Proc Natl Acad Sci USA 82:4080

163. McCaffrey PH, Friedman BA, Rosner MR 1984 Diacylglycerol modulates binding and phosphorylation of the epidermal growth factor receptor. J Biol Chem 259:12502

164. Davis RJ, Ganong BR, Bell RM, Czech MP 1985 sn-1,2-Dioctanoylglycerol. J Biol Chem 260:1562

165. Davis RJ, Ganong BR, Bell RM, Czech MP 1985 Structural requirements for diacylglycerols to mimic tumor-promoting phorbol diester action on the epidermal growth factor receptor. J Biol Chem 260:5315

166. Rackoff WR, Rubin RA, Earp HS 1984 Phosphorylation of the hepatic EGF receptor with cAMP-dependent protein kinase. Mol Cell Endocrinol 34:113

167. Ghosh-Dastidar P, Fox CF 1984 cAMP-dependent protein kinase stimulates epidermal growth factor-dependent phosphorylation of epidermal growth factor receptors. J Biol Chem 259:3864

168. Ross R, Vogel A 1978 The platelet derived growth factor. Cell $14: 203$

169. Robbins KC, Antoniades HN, Devare SG, Hunkapillar MW, Aaronson SA 1983 Structural and immunological similarities between simian sarcoma virus gene product(s) and human platelet-derived growth factor. Nature 305:605

170. Heldin C-H, Ek B, Ronnstrand L 1983 Characterization of the receptor for platelet-derived growth factor on human fibroblasts. J Biol Chem 258:10054

171. Williams LT, Tremble PM, Lain MF, Sunday ME 1984 Plateletderived growth factor receptors form a high affinity state in membrane preparations. J Biol Chem 259:5287-5294

172. Ek B, Heldin C-H 1982 Characterization of a tyrosine-specific kinase activity in human fibroblast membranes stimulated by platelet-derived growth factor. J Biol Chem 257:10486

173. Ek B, Westermark B, Wasteson, Heldin C-H 1982 Stimulation of tyrosine-specific phosphorylation by platelet-derived growth factor. Nature 295:419

174. Nishimura J, Huang JS, Deuel TF 1982 Platelet-derived growth factor stimulates tyrosine-specific protein kinase activity in Swiss Mouse 3T3 membranes. Proc Natl Acad Sci USA 79:4303

175. Pike LJ, Bowen-Pope DF, Ross R, Krebs EG 1983 Characterization of platelet-derived growth factor-stimulated phosphorylation in cell membranes. J Biol Chem 258:9383

176. Frackelton Jr AR, Tremble PM, Williams LT 1984 Evidence for the platelet-derived growth factor-stimulated tyrosine phosphorylation of the platelet-derived growth facator receptor in vivo. J Biol Chem 259:7909

177. Daniel TO, Tremble PM, Frackelton Jr AR, Williams LT 1985 Purification of the platelet-derived growth factor receptor by using an anti-phosphotyrosine antibody. Proc Natl Acad Sci USA $82: 2684$

178. Bishayee S, Ross AH, Womer R, Scher CD 1986 Purified human platelet-derived growth factor receptor has ligand-stimulated tyrosine kinase activity. Proc Natl Acad Sci USA 83:6756

179. Yarden Y, Escobedo JA, Kuang W-J, Yang-Feng TL, Daniel TO, Tremble PM, Chen EY, Ando ME, Harkins RN, Francke U, Fried VA, Ullrich A, Williams LT 1986. Structure of the receptor for platelet-derived growth factor helps define a family of closely related growth factor receptors. Nature 323:226

180. Sturani E, Vicentini LM, Zippel R, Toschi L, Pandiella-Alonso A, Comoglio PM, Meldolesi J 1986 PDGF-induced receptor phosphorylation and phosphoinositide hydrolysis are unaffected by protein kinase $\mathrm{C}$ activation in Mouse Swiss 3T3 and human skin fibroblasts. Biochem Biophys Res Commun 137:343

181. Changeux J-P 1981 The acetylcholine receptor: an "allosteric" membrane protein. Harvey Lect 75:85

182. Reynolds JA, Karlin A 1978 Molecular weight in detergent solution of acetylcholine receptor from Torpedo Californica. Biochemistry 17:2035

183. Vandlen RL, Wu WC-S, Eisenach JC, Raftery MA 1979 Studies of the composition of purified Torpedo Californica acetylcholine receptor and of its subunits. Biochemistry 18:1845

184. Gordon AS, Davis CG, Milfay D, Diamond I 1977 Phosphorylation of acetylcholine receptor by endogenous membrane protein kinase in receptor-enriched membranes of Torpedo Californica. Nature 267:539

185. Teichberg VI, Sobel A, Changeux J-P 1977 In vitro phosphorylation of the acetylcholine receptor. Nature 267:540

186. Saitoh T, Changeux J-P 1981 Change in state of phosphorylation of acetylcholine receptor during maturation of the electromotor synapse in Torpedo Mamorata electric organ. Proc Natl Acad Sci USA 78:4430 
187. Gordon AS, Milfay D, Davis CG, Diamond I 1979 Protein phosphatase activity in acetylcholine receptor-enriched membranes. Biochem Biophys Res Commun 87:876

188. Huganir RL, Miles K, Greengard P 1984 Phosphorylation of the nicotinic acetylcholine receptor by an endogenous tyrosine-specific protein kinase. Proc Natl Acad Sci USA 81:6968

189. Huganir RL, Greengard P 1983 cAMP-dependent protein kinase phosphorylates the nicotinic acetylcholine receptor. Proc Natl Acad Sci USA 80:1130

190. Zavoico GA, Comerci C, Subers E, Egan JJ, Huang C-K, Feinstein MB, Smilowitz H 1984 cAMP, not $\mathrm{Ca}^{2+} /$ calmodulin, regulates the phosphorylation of acetylcholine receptor in Torpedo Californica electroplax. Biochim Biophys Acta 770:225

191. Souroujon MC, Neumann D, Pizzighella S, Fridkin M, Fuchs S 1986 Mapping of the cAMP-dependent phosphorylation sites on the acetylcholine receptor. EMBO J 5:543

192. Albuquerque EX, Deshpande SS, Aracava Y, Alkondon M, Daly JW 1986 A possible involvement of cycle AMP in the expression of desensitization of the nicotinic acetylcholine receptor. FEBS Lett 199:113

193. Huganir RL, Delcour AH, Greengard P, Hess GP 1986 Phosphorylation of the nicotinic acetylcholine receptor regulates its rate of desensitization. Nature 321:774

194. Middleton P, Jaramillo F, Schuetze SM 1986 Forskolin increases the rate of acetylcholine receptor desensitization at rat soleus endplates. Proc Natl Acad Sci USA 83:4967

195. Stahl P, Schwartz AL 1986 Receptor-mediated endocytosis. J Clin Invest 77:657

196. Goldstein JL, Brown MS, Anderson RGW, Russel, DW, Schneider WJ 1985 Receptor-mediated endocytosis: concepts emerging from the LDL receptor system. Annu Rev Cell Biol 1:1

197. Schneider C, Owen MJ, Banville D, Williams JG 1984 Primary structure of human transferrin receptor deduced from the mRNA sequence. Nature 311:675

198. McClelland A, Kuhn LC, Ruddle FH 1984 The human transferrin receptor gene: genomic organization, and complete primary structure of the receptor deduced from a cDNA sequence. Cell 39:267

199. Klausner RD, Harford J, van Renswoude J 1984 Rapid internalization of the transferrin receptor in K562 cells is triggered by ligand binding or treatment with a phorbol ester. Proc Natl Acad Sci USA 81:3005

200. May WS, Jacobs S, Cuatrecasas P 1984 Association of phorbol ester-induced hyperphosphorylation and reversible regulation of transferrin membrane receptors in HL60 cells. Proc Natl Acad Sci USA 81:2016

201. May WS, Sahyoun N, Jacobs S, Wolf M, Cuatrecasas P 1985 Mechanism of phorbol diester-induced regulation of surface transferrin receptor involves the action of activated protein kinase $C$ and an intact cytoskeleton. J Biol Chem 260:9419

202. Davis RJ, Johnson GL, Kelleher DJ, Anderson JK, Mole JE, Czech MP 1986 Identification of serine 24 as the unique site on the transferrin receptor phosphorylated by protein kinase C. J Biol Chem 261:9034

203. Davis RJ, Czech MJ 1986 Regulation of transferrin receptor expression at the cell surface by insulin-like growth factors, epidermal growth factor and platelet-derived growth factor. EMBO J 5:653

204. Davis RJ, Corvera S, Czech MP 1986 Insulin stimulates cellular iron uptake and causes the redistribution of intracellular transferrin receptors to the plasma membrane. J Biol Chem 261:8708

205. Schwartz AL 1984 Phosphorylation of the human asialoglycoprotein receptor. Biochem J 223:481

206. Takahashi T, Nakada H, Okumura T, Sawamura T, Tashiro Y 1985 Phosphorylation of the rat hepatocyte asialoglycoprotein receptor. Biochem Biophys Res Commun 126:1054

207. Rouis M, Goldstein S, Thromopoulos P, Berthelier M, Hervy C, and Testa U 1984 Phorbol esters inhibit the binding of lowdensity lipoproteins (LDL) to U-937 monocytelike cells. J Cell Physiol 121:540

208. Kishimoto A, Brown MS, Slaughter CA, Goldstein JL 1987 Phosphorylation of serine 833 in cytoplasmic domain of low density lipoprotein receptor by a high molecular weight enzyme resembling casein kinase II. J Biol Chem 262:1344
209. Davis CG, Van Driel IR, Russel DW, Brown MS, Goldstein JL 1987 The low density lipoprotein receptor. J Biol Chem 262:4075

210. Collins MKL, Owen MJ 1985 The $\mathrm{T}$ cell antigen receptor. Biochem J 230:281

211. Borst J, Prendiville MA, Terhorst C 1983 The $\mathrm{T}_{3}$ complex on human thymus-derived lymphocytes contains two different subunits of $20 \mathrm{kDa}$. Eur J Immunol 13:576

212. Kanellopoulos JM, Wigglesworth NM, Owen MJ, Crumpton MJ 1983 Biosynthesis and molecular nature of the $T_{3}$ antigen of $\mathrm{T}$ lymphocytes. EMBO J 3:1807

213. Samelson LE, Harford JB, Klausner RD 1985 Identification of the components of the murine $\mathrm{T}$ cell antigen receptor complex. Cell 43:223

214. Samelson LE, Harford, J, Schwarz RD, Klausner RD 1985 A 20 $\mathrm{kDa}$ protein associated with the murine $\mathrm{T}$-cell antigen receptor is phosphorylated in response to activation by antigen or concanavalin A. Proc Natl Acad Sci USA 82:1969

215. Samuelson LE, Patel MD, Weissman AM, Harford JB, Klausner RD 1986 Antigen activation of murine $\mathrm{T}$ cells induces tyrosine phosphorylation of a polypeptide associated with the $\mathrm{T}$ cell antigen receptor. Cell 46:1083

216. Imboden JB, Stobo JD 1985 Transmembrane signaling by the $T$ cell antigen receptor. J Exp Med 161:446

217. Patel M, Samelson LE, Klausner RD, Multiple kinases and signal transduction: phosphorylation of the $\mathrm{T}$ cell antigen receptor complex. Nature, in press

218. Cantrell DA, Davies AS, Crumpton MJ 1985 Activators of protein kinase $\mathrm{C}$ down-regulate and phosphorylate the T3/T-cell antigen receptor complex of human T lymphocytes. Proc Natl Acad Sc USA 82:8158

219. Samelson LE, Davidson WF, Morse III HC, Klausner RD, Ab normal constituitive tyrosine phosphorylation of the $\mathrm{T}$ cell antigen receptor in murine lymphoproliferative disorders. Nature, in press

220. Greene WC, Leonard WJ 1986 The human interleukin-2 receptor Annu Rev Immunol 4:69

221. Farrar WL, Anderson WB 1985 Interleukin-2 stimulates association of protein kinase $C$ with plasma membrane. Nature 315:233

222. Leonard WJ, Depper JM, Kronke M, Robb RJ, Waldman TA Greene WC 1985 The human receptor for T-cell growth factor: evidence for variable post-translational processing, phosphorylation, sulfation and the ability of precursor forms of the receptor to bind TCGF. J Biol Chem 260:1872

223. Shackelford DA, Trowbridge IS 1984 Induction of expression and phosphorylation of the human interleukin 2 receptor by a phorbol diester. J Biol Chem 259:11706

224. Gaulton GN, Eardley DD 1986 Interleukin 2-dependent phosphorylation of interleukin 2 receptors and other $\mathrm{T}$ cell membrane proteins. J Immunol 136:2470

225. Gallis B, Lewis A, Wignall J, Alpert A, Mochizuki DY, Cosman D, Hopp T, and Urdal D 1986 Phosphorylation of the human interleukin- 2 receptor and a synthetic peptide identical to its $\mathrm{C}$ terminal, cytoplasmic domain. J Biol Chem 261:5075

226. Metzger H, Alcaraz G, Hohman R, Kinet J-P, Pribluda V, Quarto $\mathrm{R} 1986$ The receptor with high affinity for immunoglobulin $\mathrm{E}$ Annu Rev Immunol 4:419

227. Hempstead BL, Kulczycki Jr A, Parker CW 1981 Phosphorylation of the IgE receptor from ionophore A23187 stimulated intact rat mast cells. Biochem Biophys Res Commun 98:815

228. Hempstead BL, Parker CW, Kulczycki Jr A 1983 Selective phosphorylation of the IgE receptor in antigen-stimulated rat mast cells. Proc Natl Acad Sci USA 80:3050

229. Fewtrell C, Goetz A, Metzger H 1982 Phosphorylation of the receptor for immunoglobulin $\mathrm{E}$. Biochemistry 21:2004

230. Perez-Montfort G, Fewtrell C, Metzger H 1983 Changes in the receptor for Immunoglobulin E coincident with receptor-mediated stimulation of basophilic leukemia cells. Biochemistry 22:5733

231. Hanson LA, Ahlstedt A, Andersson B, Carlsson B, Cole MF, Cruz JR, Dahlgren V, Ericsson TH, Jalil F 1983 Mucosal immunity. Ann NY Acad Sci 409:1

232. Courtoy PJ, Limet JN, Quintart J, Schneider Y-J, Vaerman J-P, Bauduiin P 1983 Transfer of IgA into rat bile: ultrastructural demonstration. Ann NY Acad Sci 409:799

233. Larkin JM, Sztul ES, Palade GE 1986 Phosphorylation of the rat hepatic polymeric IgA receptor. Proc Natl Acad Sci USA 83:4759 